$4-1-2014$

\title{
Waste Animal Fats as Feedstocks for Biodiesel Production
}

\author{
Ivana B. Banković-Ilić \\ University of Niš \\ Ivan J. Stojković \\ University of Belgrade \\ Olivera S. Stamenkovic \\ University of Niš \\ Vlada B. Velijkovic \\ University of Niš \\ Yung Tse Hung \\ Cleveland State University, y.hung@csuohio.edu
}

Follow this and additional works at: https://engagedscholarship.csuohio.edu/encee_facpub

How does access to this work benefit you? Let us know!

\section{Recommended Citation}

Banković-llić, Ivana B.; Stojković, Ivan J.; Stamenkovic, Olivera S.; Velijkovic, Vlada B.; and Hung, Yung Tse, "Waste Animal Fats as Feedstocks for Biodiesel Production" (2014). Civil and Environmental Engineering Faculty Publications. 104.

https://engagedscholarship.csuohio.edu/encee_facpub/104

This Article is brought to you for free and open access by the Civil and Environmental Engineering at EngagedScholarship@CSU. It has been accepted for inclusion in Civil and Environmental Engineering Faculty Publications by an authorized administrator of EngagedScholarship@CSU. For more information, please contact library.es@csuohio.edu. 


\title{
Waste animal fats as feedstocks for biodiesel production
}

\author{
Ivana B. Banković-Ilić, Ivan J. Stojković , Olivera S. Stamenković, Vlada B. Veljkovic , \\ Yung-Tse Hung
}

\section{Introduction}

The human society, with its expansion and high technological development, is very dependent on petroleum fuel for its activities. However, fossil fuels are non-renewable resources, which take millions of years to form with limited reserves and high prices. The production and use of fossil fuel in engines with internal combustion cause environmental problems such as rising carbon dioxide levels in the atmosphere, increasing the average ambient temperature of the Earth. In consequence, a global movement toward the renewable energy sources is one way to help to meet the increased energy needs of humanity. In the group of alternate and ecologically acceptable substitutes for the conventional fuels, biodiesel has attracted an increased attention worldwide.

Beside many advantages of biodiesel over diesel fuel, such as: renewability, ready availability, portability, lower sulfur and aromatic content, higher efficiency, higher cetane number, better emission profile and safer handling [1], the high cost of biodiesel production is the main reason for its limited commercial application. The price of raw material consists of the $70-95 \%$ of the total biodiesel cost [2-5]. Since biodiesel from food-grade oils is not economically competitive with petroleum-based diesel fuel, it is necessary to use novel and lower-cost oily feedstocks for its production. The use of cheap waste cooking oils (WCOs), wasteoily by-products from edible-oil refinery, non-edible oils and

Table 1

Quantities of vegetable oils and animal fats in million tons in 2011.

\begin{tabular}{|c|c|c|c|c|c|}
\hline & $\begin{array}{l}\text { Soybean } \\
\text { oil }^{\mathrm{a}}\end{array}$ & $\begin{array}{l}\text { Palm } \\
\text { oil }^{\mathrm{a}}\end{array}$ & $\begin{array}{l}\text { Rapeseed } \\
\text { oil }^{\mathrm{a}}\end{array}$ & $\begin{array}{l}\text { Sunflower } \\
\text { oil }^{\mathrm{a}}\end{array}$ & $\begin{array}{l}\text { Animal } \\
\text { fats }\end{array}$ \\
\hline China & 10.9 & & 5.7 & & \\
\hline USA & 8.9 & & & & $4.76^{\mathrm{b}}$ \\
\hline Indonesia & & 26.2 & & & \\
\hline Malaysia & & 18.2 & & & \\
\hline $\begin{array}{c}\text { European } \\
\text { Union }\end{array}$ & & & 9.0 & & \\
\hline Ukraine & & & & 4.3 & \\
\hline Russia & & & & 3.6 & \\
\hline Australia & & & & & $0.547^{\mathrm{C}}$ \\
\hline World & 42.3 & 51.9 & 24.3 & 15.3 & \\
\hline
\end{tabular}

waste animal fats (WAFs) can improve the production economy of that sustainable and ecologically acceptable product. Before it can be accepted as biodiesel, this final product must meet stringent quality requirements (the European standard EN14214 or the USA standard ASTM D6751).

Biodiesel consists of a mixture of fatty acid alkyl esters (FAAE), derived from renewable lipid feedstocks, such as vegetable oils and animal fats, which are basically triacylglycerols (TAGs). Edible vegetable oils are commonly used for biodiesel production, but WAFs are also suitable lipid resources [6]. Quantities of edible vegetable oils and animal fats in the major production countries and in the world in 2011 are shown in Table 1. When methanol or ethanol are used in an excess as reactants in the transesterification (alcoholysis) reaction of TAGs, a mixture of fatty acid methyl esters (FAME) or fatty acid ethyl esters (FAEE), respectively is produced. Transesterification reaction can be chemically (base or acid) catalyzed using homogeneous or heterogeneous catalysts or enzyme (mostly lipases) catalyzed. When catalysts are not present, alcoholysis reactions can occur at high temperatures and pressures. It has been known that transesterification may be influenced by several factors such as: feedstock composition, free fatty acid (FFA) and water contents in raw materials, types and amount of alcohol and catalyst, mixing intensity, reaction temperature and pressure.

In this paper, a review on different methods for biodiesel production from WAFs using transesterification reactions is presented. The aim of this paper is to consider the various methods for treatment of WAFs and to give emphasis on the influence of some operating and reaction conditions on the ester yield. The possibilities of optimization, kinetics and improvement of biodiesel production from WAFs are also discussed.

\section{WAFs as sources for biodiesel production}

In general, the base feedstocks for biodiesel production can be divided into four groups: vegetable oils (edible and non-edible), animal fats, used cooking oils and algae. Ten countries in the world, including Malaysia, Indonesia, Argentina, USA, Brazil, Netherland, Germany, Philippines, Belgium, and Spain, collectively account for more than $80 \%$ of the total biodiesel production potential [1]. The main feedstocks for biodiesel production in these countries are animal fats (20\%), soybean oil (28\%), palm oil (22\%), etc.

Table 2

Fatty acid compositions of some vegetable oils and animal fats: $x x: y$ ( $x x$-number of $\mathrm{C}$ atoms, $y$-number of double bonds).

\begin{tabular}{|c|c|c|c|c|c|c|c|c|c|}
\hline \multirow[t]{2}{*}{ Feedstock } & \multicolumn{8}{|l|}{ \% (by weight) } & \multirow[t]{2}{*}{ References } \\
\hline & 12:0 (lauric) & 14:0 (myristic) & 16:0 (palmitic) & 16:1 (palmitoleic) & 18:0 (stearic) & 18:1 (oleic) & 18:2 (linoleic) & 18:3 (linolenic) & \\
\hline Rapeseed oil & & & 3.49 & & 0.85 & 64.4 & 22.3 & 8.23 & [14] \\
\hline Sunflower oil & & & 6.08 & & 3.26 & 16.93 & 73.73 & & {$[14]$} \\
\hline Soybean oil & & & 10.58 & & 4.76 & 22.52 & 52.34 & 7.19 & [15] \\
\hline Chicken fat & & 0.5 & 24 & 5.8 & 5.8 & 38.2 & 23.8 & 1.9 & [16] \\
\hline Duck tallow & & & 17 & & 4 & 59.4 & 19.6 & & [17] \\
\hline Mutton fat & 0.2 & 3 & 27 & 2 & 24.1 & 40.7 & 2 & & [18] \\
\hline Lard & & 1.7 & 23.2 & 2.7 & 10.4 & 42.8 & 19.1 & 64.7 & [19] \\
\hline Yellow grease & & 2.43 & 23.24 & 3.79 & 12.96 & 44.32 & 6.97 & 0.67 & [15] \\
\hline Brown grease & & 1.66 & 22.83 & 3.13 & 12.54 & 42.36 & 12.09 & 0.82 & [15] \\
\hline
\end{tabular}


Vegetable oils and animal fats are of two types of biological lipid materials, made up mainly of TAGs and less of di-(DAGs) and monoacylglycerols (MAGs). The fatty acid compositions of some common vegetable oils and animal fats are presented in Table 2. Saturated compounds (myristic, palmitic and stearic acid) have higher cetane numbers and are less prone to oxidation than unsaturated compounds, but they tend to crystallize at high temperatures [10]. Oils and fats have similar chemical structures and physical properties such as water-insolubility, hydrophobicity and solubility in nonpolar organic solvents. However, the animal fats have not been studied for biodiesel production as extensively as vegetable oils. The very high fatty acids content in fats and the various distributions of fatty acids are the main differences between them [11]. In addition, oils are generally liquid at room temperature, while many animal fats and greases tend to be predominantly solid because of their high content of saturated fatty acids (SFA) [12]. Since many animal meat processing facilities, rendering companies collecting and processing of animal mortalities, large food processing and service facilities create large amount of WAFs, it can be a great opportunity to obtain biodiesel from these very cheap raw materials. The use of WAFs as feedstock for biodiesel production eliminates the need of their disposal, besides contributing to the supply of biodiesel [13].

Different WAFs can be used as feedstocks for biodiesel production. They are: tallow (beef tallow from domestic cattle and mutton tallow from sheep), pork lard (rendered pork fat), chicken fat and grease.

Tallow is a waste final product which is generated in slaughterhouses, processing facilities or by rendering operations. Lard is extracted from swine slaughter residues. Its specification and quality guarantees the same as for tallow. Different types of WAFs consist of various and mostly high amount of SFA (sum of myristic, palmitic and stearic acids). Usually, tallow and pork lard consist of more than 40\% SFA. According to [20], the SFA content in beef tallow is $45.6 \%$, mutton tallow $61.1 \%$, lard $39.3 \%$ and chicken fat $32 \%$. As a result, the synthesis of biodiesel from WAFs should be conducted at higher temperature which is unlike the conversion processes of used cooking oils [21]. The chicken fat is about 30$33 \%$ of saturation fat, and thus it is almost liquid, very viscous and in the semi-solid form. Recycled greases are also waste greases and generally can be classified on the basis of the FFA level in two categories, yellow grease and brown grease. Yellow greases have FFA content of less than $15 \%(\mathrm{w} / \mathrm{w})$. They are produced from heated animal fats and vegetable oils which are collected from commercial and industrial cooking business. Brown greases refer to waste materials in which the amount of FFA exceeds $15 \%$. Sometimes they are named as trap greases, i.e. materials that are collected in special traps in restaurants to prevent the grease from entering the sanitary sewer system. They are very cheap materials in comparison with edible vegetable oils and often used as potential feedstocks for biodiesel production. The first biodiesel plants in the world which use trap grease, WAFs, WCO and palm fatty acid distillate as feedstocks were built in Netherlands and Hong Kong in 2010 and 2011, respectively, both with the same capacities of $100.000 \mathrm{t} /$ year [22].

In the last decade, biodiesel production in the world has increased rapidly, reaching a level of $2.54 \times 10^{6} \mathrm{~m}^{3}$ per day in 2011 [23]. In 2008, all over the world, about 1 million $t$ of biodiesel were produced from rendering products, which was nearly $10 \%$ of the total biodiesel production during the same year [24]. In the USA, approximately $8-10 \%$ of available rendered fats are currently used for biofuels, and it can be obtained $4.5 \times 10^{5} \mathrm{~m}^{3}$ of biodiesel. In 2008 , almost $20 \%$ of biodiesel was produced from animal fats and greases, which is nearly double the production in 2007. In Canada, almost $90 \%$ of produced biodiesel was derived from animal fats and greases [24]. The Energy Information Administration (EIA), however, assumed that competing uses would limit biodiesel production from yellow grease to $3.8 \times 10^{5} \mathrm{~m}^{3}$ per year $\left(1 \mathrm{~m}^{3}\right.$ per day) [25]. Although at a glance the high amounts of WAFs are generated in the world, their available amounts are limited actually, and these feedstocks will never meet the world's fuel needs.

Today, the high selling price of biodiesel is the major barrier to its commercialization. Compared to petroleum diesel fuel ( 0.35 US $\$ / \mathrm{L}$ ), it is more expensive (usually $0.5 \mathrm{US} \$ / \mathrm{L}$ ) [26], although it depends on the geographic area, production of crops, the price of crude petroleum and other factors. The major economic parameter determining the selling price is the cost of raw material. Because of favorable price of animal fats related to vegetable oils, they offer an economic advantage. For example, average international prices for poultry fat, yellow grease and WCO used for biodiesel production in 2007 were 256, 374 and about 200 US\$/t, respectively, which are 2.5-3.5 times lower than price for virgin vegetable oils of 500-800 US\$/t [2]. Generally, when compare costs of traditional transesterification of vegetable oils (around US\$ 0.6-0.8 per liter) and WAFs (US\$ 0.4-0.5 per liter) currently, the cheapest option is biodiesel production from waste fats [2]. Rice et al. [27] have reported that biodiesel produced from tallow in a plant with annual capacity of $3000 \mathrm{t}$ would have a cost of about $0.27 \mathrm{US} \$ / 1$. Though the use of WAFs for biodiesel production has helped to reduce the biodiesel price, yet more investigations and technological development will be needed.

\section{Fuel properties of biodiesel from WAFs}

In the engines with internal combustion, biodiesel can be used as pure fuel or blended at any level with petroleum diesel. Pure biodiesel (B100) may be used in some engines with little or no modifications, although there may be problems with its storage and transportation. Blends noted as B2 (2\% biodiesel and 98\% petroleum diesel), B5 (5\% biodiesel and 95\% petroleum diesel) and B20 (20\% biodiesel and 80\% petroleum diesel) are the most common biodiesel blends, although these mixture have some technical disadvantages like freezing problem in cold weather, reduced energy density and fuel degradation under longer storage.

The oil/fat quality and its fatty acid composition have the most important effect on fuel properties of biodiesel. These properties can play a vital role in quality control of product and can be divided into two groups: the first contains major parameters as for mineral oil-based fuel and second especially describes the chemical composition and purity of FAAE [28]. Composition and physical properties of biodiesel produced from WAFs are presented in Table 3. For comparison, the provisional standards for biodiesel according to EN14214 are added.

Density is a factor which influences the efficiency of atomization and depends on alkyl esters content and the remained amount of alcohol. The density values between 860 and $900 \mathrm{~kg} /$ $\mathrm{m}^{3}$ are adopted by the EN14214 standard.

The viscosity of biodiesel is influenced primarily by the experimental conditions and the extent of the transesterification reaction [28]. Different values of viscosities for esters originated from the same type of feedstock are the consequence of incomplete reaction of the WAF, i.e. the presence of acylglycerols and inherent biodiesel purification. The higher viscosity of beef tallow biodiesel than the established limit is because of high content of high molecular weight SFA [32]. When compare the kinematic viscosities of biodiesel obtained from different feedstocks, it was observed that lard and chicken fat biodiesel have higher values than the standard limit $[33,34]$. When the flash point of biodiesel is high, biodiesel is safer to handle, transport and store and in this case the risk of fire decreases. Most researchers [31-34,39-41] have shown that flash point of WAFs biodiesel was significantly 
Table 3

Properties of biodiesel produced from WAFs ${ }^{\mathrm{a}}$.

\begin{tabular}{|c|c|c|c|c|c|c|c|c|c|c|c|c|c|c|c|c|}
\hline $\begin{array}{l}\text { Feedstock } \\
\text { Technology } \\
\text { Property, unit }\end{array}$ & $\begin{array}{l}\text { WAF } \\
\text { B, AC, HC, } \\
\text { Et }\end{array}$ & $\begin{array}{l}\text { Beef } \\
\text { tallow } \\
\mathrm{B}, \mathrm{BC}, \mathrm{HC} \text {, } \\
\mathrm{Me}\end{array}$ & $\begin{array}{l}\text { Beef } \\
\text { tallow } \\
\text { B, BC, HC, } \\
\text { Me }\end{array}$ & $\begin{array}{l}\text { Beef } \\
\text { tallow } \\
\mathrm{B}, \mathrm{BC}, \mathrm{HC} \text {, } \\
\mathrm{Me}\end{array}$ & $\begin{array}{l}\text { Mutton } \\
\text { tallow } \\
\mathrm{B}, \mathrm{TS}, \mathrm{HC} \text {, } \\
\mathrm{Me}\end{array}$ & $\begin{array}{l}\text { Mutton } \\
\text { fat }\end{array}$ & $\begin{array}{l}\text { Lard } \\
\mathrm{B}, \mathrm{AC}, \mathrm{HC} \text {, } \\
\mathrm{Me}\end{array}$ & $\begin{array}{l}\text { Lard } \\
\text { B,TS, HC, } \\
\mathrm{Me}\end{array}$ & $\begin{array}{l}\text { Lard } \\
\mathrm{B}, \mathrm{BC}, \mathrm{SC} \text {, } \\
\mathrm{Me}\end{array}$ & $\begin{array}{l}\mathrm{B}, \mathrm{BC}, \\
\mathrm{HC}, \mathrm{Me}\end{array}$ & $\begin{array}{l}\text { Lard } \\
\text { B,EC, } \\
\text { e } \mathrm{Me}\end{array}$ & $\begin{array}{l}\text { Poultry } \\
\text { fat } \\
\text { B, BC, HC, } \\
\text { Me }\end{array}$ & $\begin{array}{l}\text { Chicken } \\
\text { fat } \\
\text { - }\end{array}$ & $\begin{array}{l}\text { Chicken } \\
\text { fat } \\
\text { B,TS, HC, } \\
\text { Me }\end{array}$ & $\begin{array}{l}\text { Chicken fat } \\
\text { B, BC, SC, } \\
\text { Me }\end{array}$ & $\begin{array}{l}\text { EN14214 limits } \\
\min / \max \end{array}$ \\
\hline FAME content, $\%$ & & & 97 & 82.5 & & & 85.1 & $\begin{array}{l}69.6- \\
99.6\end{array}$ & 92.5 & 94.4 & & 67.25 & & & & $96.5 \mathrm{~min}$ \\
\hline Density at $15^{\circ} \mathrm{C}, \mathrm{kg} / \mathrm{m}^{3}$ & 873 & $832^{\mathrm{c}}$ & 872 & 870 & 882 & 856 & 873 & & & & 877.4 & 877 & 867 & 883 & 870 & $860 / 900$ \\
\hline Viscosity at $40^{\circ} \mathrm{C}, \mathrm{mm}^{2} / \mathrm{s}$ & $7.06^{\mathrm{c}}$ & 4.89 & 5.3 & 5.35 & 4.75 & 5.98 & 5.08 & $4.64-7.73$ & 4.59 & 4.714 & 4.84 & 6.86 & 6.25 & 4.94 & 5.4 & $3.50 / 5.00$ \\
\hline Flash point, ${ }^{\circ} \mathrm{C}$ & $<25$ & 152 & 156.7 & 171 & & & 147 & & & & 143.5 & 172 & & 171.8 & 174 & $101 \min$ \\
\hline Sulfur content, $\mathrm{mg} / \mathrm{kg}$ & 230 & & & & & & & & & & & & & & & $10 \max$ \\
\hline $\begin{array}{l}\text { Carbon residue (on 10\% distillation } \\
\text { residue), \% }\end{array}$ & & & & & & & & & & & 0.21 & & & & 0.024 & $0.3 \max$ \\
\hline Cetane number & & & 60.36 & & 59 & 59 & & & & & & & 61 & & 58.4 & $51 \mathrm{~min}$ \\
\hline Sulfated ash content, \% & & & & & & 0.025 & & & & & 0.002 & & & & 0.03 & $0.02 \max$ \\
\hline Water content, $\mathrm{mg} / \mathrm{kg}$ & & & & 374.2 & & & 184 & $340-470$ & 400 & 11002 & 200 & 1201 & & 200 & & $500 \max$ \\
\hline Total contamination, $\mathrm{mg} / \mathrm{kg}$ & & & & & & & & & & & & & & & & $24 \max$ \\
\hline $\begin{array}{l}\text { Copper strip corrosion ( } 3 \mathrm{~h} \text { at } \\
50^{\circ} \mathrm{C} \text { ), rating }\end{array}$ & & & & 1 & & & 1 & & & & & 1 & & 1 & & Class 1 min \\
\hline Oxidation stability at $110^{\circ} \mathrm{C}, \mathrm{h}$ & & & & & & & & & & & & & & & 6.0 & $6.0 \mathrm{~min}$ \\
\hline Acid value, mg KOH/g & & & & 0.2 & 0.3 & 0.65 & 0.22 & 1.13 & 0.25 & $0.04 \quad 0$ & 0.12 & 0.55 & 0.25 & 0.22 & 0.8 & 0.5 \\
\hline Iodine value, $\mathrm{g} \mathrm{I}_{2} / 100 \mathrm{~g}$ & & & & 44.4 & 40 & 126 & 75.6 & 77 & 68 & 67 & & 78.8 & 130 & & & 120 \\
\hline Linolenic methyl ester content, \% & & & & & & & & 1.4 & 0.9 & 1.0 & & & & & & $12 \max$ \\
\hline Methanol content, \% & & & 0.1 & & & & & & & & & & & 0.01 & 0.06 & $0.20 \max$ \\
\hline MAG content, \% & $<0.1$ & & 0.13 & & & & & & & & & & & 0.56 & & $0.80 \max$ \\
\hline DAG content, \% & $<0.05$ & & 0.12 & & & & & & & & & & & 0.09 & & $0.20 \max$ \\
\hline TAG content, \% & $<0.05$ & & 0.07 & & & & & & & & & & & 0.12 & & $0.20 \max$ \\
\hline Free glycerol, \% & $<0.005$ & & 0.01 & & & & & & & & & & & 0.02 & 0.004 & $0.02 \max$ \\
\hline Total glycerol, \% & $<0.1$ & & 0.33 & & & & & & & & & & & 0.19 & & $0.25 \max$ \\
\hline Group I metals $(\mathrm{Na}+\mathrm{K}), \mathrm{mg} / \mathrm{kg}$ & & & $<2.63$ & 2 & & & 17.2 & & & & & 46.8 & & & 5 & $5.0 \max$ \\
\hline Group II metals $(\mathrm{Ca}+\mathrm{Mg}), \mathrm{mg} / \mathrm{kg}$ & & & & & & & & & & & & & & & 2 & $5.0 \max$ \\
\hline Phosphorus content, $\mathrm{mg} / \mathrm{kg}$ & & & & & 16 & & & & & & & & & & 100 & $4.0 \max$ \\
\hline Cloud point, ${ }^{\circ} \mathrm{C}$ & 5 & & & & & -4 & & & & & & & -5 & & 14 & Not specified \\
\hline Pour point, ${ }^{\circ} \mathrm{C}$ & 3 & 15 & 14.3 & 10 & -5 & -5 & 5 & & & & 7 & 3 & -6 & 2 & 12.3 & Not specified \\
\hline Higher heating value, $\mathrm{MJ} / \mathrm{kg}$ & 38.76 & & & 40.23 & & & 40.10 & & & & 36.5 & 39.58 & & 40.17 & 39.34 & Not specified \\
\hline Distillation range temperatures, ${ }^{\circ} \mathrm{C}$ & & & $307-344$ & & & & & & & & 352.5 & & & & & Not specified \\
\hline Reference & [30] & [31] & [32] & {$[33,34]$} & [35] & [36] & {$[33,34]$} & [37] & [38] & & [39] & {$[33,34]$} & [36] & {$[40,41]$} & [42] & \\
\hline
\end{tabular}

a Adapted from [29].

b B - batch, C - continuous, TS - two step, AC - acid catalyst, BC - base catalyst HC - homogeneous catalysis, SC - heterogeneous catalysis, EC - enzyme catalysis, Me - methanol, Et - ethanol. ${ }^{c}$ At $20^{\circ} \mathrm{C}$. 
higher than that of standard limit. However, too high a flash point of chicken fat and tallow biodiesel is not recommendable because it may cause ignition problems in the engine [33,34,40,41].

Cold filter plugging point (CFPP) refers on the use of biodiesel in the cold weather performances. Similar to CFPP, which defines the fuel's limit of filterability, the cloud and pour point are often used to specify cold temperature usability of fuel and indicative of a high concentration of saturated fatty esters in the product. The cloud point is the temperature at which a liquid fatty material becomes cloudy due to formation of crystals and solidification of saturates [6]. The pour point is the lowest temperature at which the substance will still flow. Biodiesel obtained from fats with significant amounts of SFA will have higher CFPP. So, biodiesel from beef tallow has a higher CFPP than limit [31-34].

Cetane number is a measure of the ignition properties as one of biodiesel quality and influences engine characteristics such as combustion, stability, noise, white smoke and carbon monoxide and hydrocarbon emission. The cetane number of WAFs biodiesel is higher than the specified minimum limit that makes them attractive as an alternative fuel [18,32,42]. Because of greater content of SFA, biodiesel from WAFs has higher cetane number than biodiesel from soy oil (48-52) and petrodiesel (40-44) [43]. When such biodiesel was added to petrodiesel this fuel allows faster start of engine and more quiet operation. The acid value, as the measure of FFA content in the fuel, is specified to ensure proper fuel aging and a good manufacturing process. The most of WAFs biodiesel samples [33,34,38,40,41] have the acid value below the maximum standard limit. Comparing homo- and heterogeneously catalyzed methanolysis of lard, Dias et al. [38] concluded that the acid value of obtained biodiesel was significantly lower when the homogeneously catalyst was used. Such differences exist, because the homogeneous catalyst tends to react with FFA and generate soaps, which reduced the acid value. Iodine value defines the degree of unsaturation of biodiesel and influences fuel oxidation and the type of aging products. Several samples of biodiesel obtained from WAFs have iodine number lower than standard limit $[33,34,38,40,41]$.

Methanol contaminates ester phase and affect metal corrosion. Thus, it is necessary to achieve low methanol content in the biodiesel fuel $[32,40,41]$. The presence of MAGs, DAGs and TAGs causes problems in engine as filter plugging which affects the fuel properties. The amount of $\mathrm{Na}+\mathrm{K}$ suggests that purification methods were not effective, leaving catalyst residues dissolved in the biodiesel. Only for the purified tallow biodiesel, the amount of $\mathrm{Na}+\mathrm{K}$ is within the standard limit. Teixeira et al. [31] reported that the water content of chicken fat biodiesel was very high, but lard biodiesel presented a low value. However, tallow biodiesel purified with water satisfied the standard maximum limit.

\section{Transesterification methods for modification of WAFs into biodiesel}

In general, depending on the presence of the catalyst in the process, there are two methods of transesterification of TAGs into biodiesel: catalyzed and non-catalyzed. According to the type of catalyst employed, the reactions can be classified into three groups: homogeneously-, heterogeneously- and enzymaticallycatalyzed. The transesterification reactions are conventionally performed using homogeneous base or acid catalysts. Different groups of heterogeneous catalysts such as: metallic, solid bases, solid acids and natural catalysts [44] can be also applied for efficiently converting oil/fat to ester. Recently, bio-catalysts like free-suspended or immobilized lipases were used as very promising reaction agents, although they have not yet been commercialized because of high price of operation. The fourth, non-catalyzed processes as supercritical transesterification reactions were designed to overcome the problems with a series of industrial process steps and high production costs. All four types of transesterification reaction have been employed for biodiesel production from WAFs.

\subsection{Homogeneously catalyzed processes}

The most of researchers have investigated different one- and two-step processes of homogeneously catalyzed alcoholysis of WAFs aiming at high biodiesel yield. Homogeneous reaction conditions usually include alcohol:fat molar ratio around 6:1, catalyst amount of about $1 \%$ (based on the WAFs weight), reaction temperature of $60{ }^{\circ} \mathrm{C}$ and time of $1 \mathrm{~h}$.

\subsubsection{One-step processes}

Usually, WAFs contain high FFA content (or have high acid value) that is the main factor determining the use of base or acid catalyst in the biodiesel production processes via transesterification reaction. The presence of base catalysts in the reaction mixture influences soap formation, catalyst loss and ester yield reduction. Also, they have a negative effect on process economy by complicating separation of final products (biodiesel and glycerol) [45]. Therefore, the use of base catalysts is preferable when WAFs have a lower FFA content. On the other hand, acid catalysts have the ability to catalyze reactions of both esterification of FFAs and transesterification of TAGs simultaneously. The use of acid catalysts in the transesterification reaction has advantages such as less sensitivity towards the high FFA presence in the low-cost feedstocks ( $>6 \%$ ) [46]. But, compared to the base catalyzed process, the acid-catalyzed processes will need longer reaction time, higher reaction temperature and higher alcohol:oil molar ratios [36,47].

Another important factor that can affect the TAG conversion is content of water in WAFs. Water has a more negative effect on transesterification reaction than the presence of FFAs [48]. Usually, the water content of WAF is relatively low but in the case of base catalysts, the conversion is slightly reduced when more water is present. When the acid catalyst is used, the addition of only $0.1 \%$ of water can cause some ester yield reduction.

Because of some disadvantages in use of base and acid catalysts in the homogeneously catalyzed alcoholysis of WAFs, the alternative methods have been developed. Table 4 summarizes the catalyst type and the optimum reaction conditions for some homogeneously catalyzed (base and acid) transesterification of WAFs.

4.1.1.1. Base catalysis. There are a number of the important factors which influence the reaction rate and biodiesel yield, such as presence of water and FFAs in feedstock, concentration of catalyst, alcohol:fat molar ratio and reaction time and temperature.

A pretreatment step is needed to reduce or eliminate water and FFAs in raw material because their presence can negatively influence biodiesel yield. The reported data show that the water and FFA contents in WAFs should be kept below $0.06 \%$ and $0.5 \%$, respectively [56]. Duck tallow with $0.28 \%$ FFAs [17], beef tallow with $0.3-0.9 \%$ FFAs [31,32] and lard with $0.33 \%$ FFA [52] were successfully processed using homogeneous base catalysts and methanol. At the other side, Araújo et al. [57] treated beef tallow with high quantities of FFAs (3.6\%) after heating and forming a microemulsion, and a high biodiesel yield (96.26\%) was achieved. To reduce water content, the WAF must be heated over $100{ }^{\circ} \mathrm{C}$.

$\mathrm{KOH}$ and $\mathrm{NaOH}$ are the most used base catalysts in homogeneous transesterification processes with the optimum concentrations in the range of $0.5-1 \%$ or little more, such as $2 \%$ (based on fat weight) [6], which depends on types of WAF. It was reported that an increase of catalyst amount increased the biodiesel yield at a constant reaction temperature $[17,36,49,52]$. Beyond certain 
Table 4

A review of homogeneous one-step transesterification processes of different WAFs

\begin{tabular}{|c|c|c|c|c|c|c|c|c|}
\hline \multirow[t]{2}{*}{ Type of animal fat } & \multirow{2}{*}{$\begin{array}{l}\text { Type, volume of reactor, } \mathrm{cm}^{3} / \text { type of } \\
\text { agitator, agitation intensity, rpm }\end{array}$} & \multirow{2}{*}{$\begin{array}{l}\text { Type of } \\
\text { alcohol }\end{array}$} & \multirow{2}{*}{$\begin{array}{l}\text { Alcohol:fat molar } \\
\text { ratio, } \mathrm{mol} / \mathrm{mol}\end{array}$} & \multirow{2}{*}{$\begin{array}{l}\text { Catalyst/loading, } \\
\mathrm{wt} \% \text { to the fat }\end{array}$} & \multirow{2}{*}{$\begin{array}{l}\text { Temperature, } \\
{ }^{\circ} \mathrm{C}\end{array}$} & \multicolumn{2}{|c|}{ Optimal reaction conditions } & \multirow[t]{2}{*}{ Reference } \\
\hline & & & & & & $\begin{array}{l}\text { Reaction } \\
\text { conditions }\end{array}$ & $\begin{array}{l}\text { Yield } \\
\text { (Conversion), } \\
\% / T i m e, ~ h\end{array}$ & \\
\hline \multicolumn{9}{|l|}{ Base catalysis } \\
\hline Bovine fat & Tubular $^{\text {a }}$ & Methanol & & $\mathrm{KOH} / 2$ & 65 & & $(95) / 1.5$ & {$[6]$} \\
\hline Beef tallow & Pilot plant ${ }^{a /}$ Mechanical, 400 & Methanol & $6: 1$ & $\mathrm{KOH} / 1.5$ & 65 & & $(96.4) / 3$ & [32] \\
\hline Beef tallow & Vessel, 2000/Mechanical, 600 & Methanol & $6: 1$ & $\mathrm{KOH} / 0.5$ & 60 & & $(91) / 1(92)^{b} / 0.02$ & [31] \\
\hline Beef tallow & Flask, -/-, 150 & Methanol & $3: 1-12-12: 1$ & $\mathrm{KOH} / 0.75-1.75$ & $55-65$ & $\begin{array}{l}6: 1,1.25 \% \\
65{ }^{\circ} \mathrm{C}\end{array}$ & $87.4 / 2$ & [49] \\
\hline Beef tallow & Flask, -/Magnetic, - & Methanol & $9: 1$ & $\mathrm{NaOH} / 0.6$ & 20 & & $(96.3)^{c} / 0.083$ & {$[50]$} \\
\hline Tallow & Flask, 1000/Magnetic, - & Methanol & $6: 1$ & $\mathrm{NaOH} / 0.5$ & 60 & & -13 & [12] \\
\hline Tallow & Flask, -/Magnetic, - & Methanol & $6: 1$ & $\mathrm{KOH} / 1.5$ & $50-55$ & & $55.6 / 1$ & [51] \\
\hline Duck tallow & Flask, 500/Mechanical, 600 & Methanol & $3: 1-18: 1$ & $\mathrm{KOH} / 0.5-3$ & $55-85$ & $\begin{array}{l}6: 1,1 \% \\
65^{\circ} \mathrm{C}\end{array}$ & $97.1 / 3$ & [17] \\
\hline Beef tallow & Flask, 1000/Shaking, 60 & Methanol & $6: 1$ & $\mathrm{KOH} / 0.8$ & 60 & & $90.8 / 2$ & {$[33,34]$} \\
\hline Pork lard & & & & & & & $91.4 / 2$ & \\
\hline Chicken fat & & & & & & & $76.8 / 2$ & \\
\hline Chicken fat & Flask, 250/Mechanic, 900 & & $3: 1-7: 1$ & $\mathrm{KOH} / 0.34-0.41$ & 60 & $6: 1,0.38 \%$ & $95.2 / 1.5$ & [35] \\
\hline Chicken fat & Flask, -/-, 150 & Methanol & $3: 1-12-12: 1$ & $\mathrm{KOH} / 0.75-1.75$ & $55-65$ & $\begin{array}{l}6: 1,1.25 \% \\
65{ }^{\circ} \mathrm{C}\end{array}$ & $89.2 / 2$ & [49] \\
\hline Chicken fat & Flask, 250/Magnetic, 130 & Methanol & $33.5 \mathrm{~cm}^{3}: 120 \mathrm{~g}$ & $\mathrm{KOH} / 1.5$ & 30 & & $88.4 / 1$ & [36] \\
\hline Mutton fat & Flask, 250/Magnetic, 130 & Methanol & $33.5 \mathrm{~cm}^{3}: 120 \mathrm{~g}$ & $\mathrm{KOH} / 1.5$ & 30 & & $78.3 / 1$ & {$[36]$} \\
\hline Lard & Four-necked reactor, $1000 /$ propeller & Methanol & $3.48: 1-8.52: 1$ & $\mathrm{KOH} / 0.16-1.84$ & $24.8-75.2$ & $\begin{array}{l}7.5: 1 \\
1.26 \% \\
65^{\circ} \mathrm{C}\end{array}$ & $97.8 / 0.33$ & {$[52]$} \\
\hline $\begin{array}{l}\text { Mixture of soybean } \\
\text { oil and pork lard } \\
(1: 4 \mathrm{w} / \mathrm{w})\end{array}$ & Flask, 1000/Magnetic, - & Methanol & $6: 1$ & $\mathrm{NaOH} / 0.8$ & 60 & & $88.6 / 1$ & [53] \\
\hline \multirow[t]{2}{*}{ Catfish fat } & & Methanol & $6: 1$ & $\mathrm{KOH} / 0.8$ & 50 & & $92.7 / 0.75$ & {$[54]$} \\
\hline & & & $12: 1$ & $\mathrm{KOH} / 0.8$ & 47 & & $92.7^{\mathrm{d}} / 0.33$ & \\
\hline \multicolumn{9}{|l|}{ Acid catalysis } \\
\hline Chicken fat & Flask, 250/magnetic, 130 & Methanol & $30: 1$ & $\begin{array}{l}\text { conc. } \mathrm{H}_{2} \mathrm{SO}_{4} / 25- \\
100\end{array}$ & $30-60$ & $50{ }^{\circ} \mathrm{C}, 25 \%$ & $99 / 24$ & [36] \\
\hline Mutton fat & Flask, 250/magnetic, 130 & Methanol & $30: 1$ & $\begin{array}{l}\text { conc. } \mathrm{H}_{2} \mathrm{SO}_{4} / 25- \\
100\end{array}$ & $30-60$ & $60{ }^{\circ} \mathrm{C}, 50 \%$ & $93.2 / 24$ & [36] \\
\hline Fat $(10.7 \%$ FFA $)$ & Glass reactor, 1000/mechanical & Methanol & $6: 1-18: 1$ & $\mathrm{H}_{2} \mathrm{SO}_{4} / 5-9$ & $35-65$ & $\begin{array}{l}6: 1,9 \% \\
60{ }^{\circ} \mathrm{C}\end{array}$ & $89 / 48$ & {$[47]$} \\
\hline Fat $(10-15 \%$ FFA $)$ & - & Ethanol & $-{ }^{e}$ & $\mathrm{H}_{2} \mathrm{SO}_{4} / 10$ & $50-90$ & $\begin{array}{l}50{ }^{\circ} \mathrm{C} \\
100 \%\end{array}$ & $(78) / 2$ & [30] \\
\hline \multirow[t]{2}{*}{ Fats, oil and grease } & Bottle, 250/shaking, 200 & Methanol & $10: 1-26: 1$ & $\mathrm{H}_{2} \mathrm{SO}_{4} / 1-10$ & 30 & $20: 1,10 \%$ & $93.8^{\mathrm{f}} / 24$ & {$[55]$} \\
\hline & & Methanol & $10: 1-26: 1$ & $\mathrm{Fe}_{2}\left(\mathrm{SO}_{4}\right)_{3} / 1-10$ & 30 & $26: 1,10 \%$ & $45^{\mathrm{f}} / 24$ & \\
\hline
\end{tabular}

a Capacity $800 \mathrm{~kg} /$ day.

${ }^{\mathrm{b}}$ Ultrasonic heating $(400 \mathrm{~W}, 24 \mathrm{kHz})$.

${ }^{c}$ Radio frequency heating $(0.7 \mathrm{~kW}, 27.12 \mathrm{MHz})$.

${ }^{\mathrm{d}}$ Ultrasonic heating $(20 \mathrm{kHz})$.

e Excess of alcohol 100-200\%.

${ }^{\mathrm{f}}$ Reduction of FFA content (\%).

catalyst concentration, soap formation complicated biodiesel separation from glycerol fraction, increased the biodiesel viscosity and decreased the FAME yield [36,49]. Also, Chung et al. [17] compared the different types of base catalysts under the same operating conditions and showed that the lower FAME yield was obtained from duck tallow using $\mathrm{CH}_{3} \mathrm{NaO}$ (83.6\%) and $\mathrm{NaOH}$ (81.3\%) than $\mathrm{KOH}(97 \%)$.

The alcohol:fat molar ratio usually used in the base-catalyzed transesterification of WAFs is $6: 1$ [12,31-35,51,53], although somewhat higher ratios, such as 7.5:1 [52] or 9:1 [50], have been also employed. The FAME yield did not increase when the alcohol: fat molar ratio increased above the molar ratio of $6: 1$, since the excess of methanol deactivated the catalyst [17,35,49]. Authors generally agreed that the increase of the initial alcohol:fat molar ratio up to a certain limit increased the ester yield $[17,49,50]$. However, at industrial scale increasing the amount of methanol is not a problem, since methanol is recovered from ester and glycerol phases [35].

Different reaction times for completing the base-catalyzed transesterification processes of WAFs have been reported. It was found that these processes required about $1-3 \mathrm{~h}$, except much shorter reaction time $(20 \mathrm{~min})$ in the case of the lard methanolysis [52], beef tallow methanolysis in the presence of ultrasound (70 s) [31] and radio frequency heating (5 min) [50]. The TAG conversion from WAFs increases with the reaction time [17,49,50]. Generally, it was observed that most of the methanolysis process occurs during the second hour [49].

The TAG conversion from WAFs has not been investigated in the wide range of temperature. The reaction temperature is usually maintained close to but below the boiling point of alcohol. The optimum temperature for methanolysis of WAFs is about $60-65{ }^{\circ} \mathrm{C}$, independent of type of base catalyst. Some researchers suggest lower temperature such as $20^{\circ} \mathrm{C}$ in the case of beef tallow methanolysis using radio frequency heating [50] and $30^{\circ} \mathrm{C}$ for the methanolysis of chicken and mutton fat [36], though the lower ester yield was achieved in the latter cases. Some authors [17,52] used different temperatures in the alcoholysis processes of WAFs and clearly showed that the average FAME yield proportionately increased with the increase in reaction temperature (roughly by $5 \%$ for every $5{ }^{\circ} \mathrm{C}$ increase) $[17,49,52]$. 
Table 5

A review of the two-step (acid/base) catalyzed transesterification processes of different WAFs (I-first step: acid pretreatment, II-second step: base-catalyzed).

\begin{tabular}{|c|c|c|c|c|c|c|c|c|c|}
\hline \multirow{2}{*}{$\begin{array}{l}\text { Type of animal } \\
\text { fat }\end{array}$} & \multirow{2}{*}{$\begin{array}{l}\text { Type, volume of reactor, } \mathrm{cm}^{3} / \\
\text { type of agitator, agitation } \\
\text { intensity, rpm }\end{array}$} & \multirow[t]{2}{*}{ Step } & \multirow{2}{*}{$\begin{array}{l}\text { Type of } \\
\text { alcohol }\end{array}$} & \multirow{2}{*}{$\begin{array}{l}\text { Alcohol:fat molar } \\
\text { ratio, } \mathrm{mol} / \mathrm{mol}\end{array}$} & \multirow{2}{*}{$\begin{array}{l}\text { Catalyst/loading, } \\
\text { wt\% to the fat }\end{array}$} & \multirow{2}{*}{$\begin{array}{l}\text { Temperature, } \\
{ }^{\circ} \mathrm{C}\end{array}$} & \multicolumn{2}{|c|}{ Optimal reaction conditions } & \multirow[t]{2}{*}{ Reference } \\
\hline & & & & & & & $\begin{array}{l}\text { Reaction } \\
\text { conditions }\end{array}$ & $\begin{array}{l}\text { FFA conversion, } \\
\% / \text { Yield, \%/Time, h }\end{array}$ & \\
\hline \multicolumn{10}{|c|}{ Homogeneous catalysis } \\
\hline \multirow[t]{2}{*}{ Tallow } & Flask, 250/-, 900 & I & Methanol & $3: 1-7: 1$ & $\mathrm{H}_{2} \mathrm{SO}_{4} / 1$ & 60 & $6: 1$ & $-/ 1$ & [18] \\
\hline & & II & Methanol & $3: 1-7: 1$ & $\mathrm{KOH} / 0.35-0.4$ & 60 & $5: 1,0.39 \%$ & $94 / 1.5$ & \\
\hline \multirow[t]{2}{*}{ WAF } & Vessel, 1000/Magnetic, 700 & I & Methanol & $20: 1$ & $\mathrm{H}_{2} \mathrm{SO}_{4} / 6-10$ & 40 & $8 \%$ & $-/ 1$ & {$[60]$} \\
\hline & & II & Methanol & $25: 1-40: 1$ & $\mathrm{NaOH} / 0.5-1.5$ & $50-70$ & $\begin{array}{l}35: 1,1 \% \\
62{ }^{\circ} \mathrm{C}\end{array}$ & $89 / 1$ & \\
\hline \multirow[t]{2}{*}{ WAF (10.7\% FFA) } & Flask, 1000/Mechanical, - & I & Methanol & $3: 1-18: 1$ & $\mathrm{H}_{2} \mathrm{SO}_{4} / 0.1-1$ & $35-65$ & $\begin{array}{l}6: 1,0.5 \% \\
65{ }^{\circ} \mathrm{C}\end{array}$ & $94.9 / 4$ & {$[47]$} \\
\hline & & II & Methanol & $3: 1-12: 1$ & $\mathrm{KOH} / 0.1-1.5$ & 65 & $6: 1,0.5 \%$ & $97.3 / 2$ & \\
\hline \multirow[t]{2}{*}{ WAF (12.1\% FFA) } & Flask, -/Magnetic, - & I & Methanol & $20: 1-30: 1$ & $\mathrm{H}_{2} \mathrm{SO}_{4} / 1-15$ & 60 & $30: 1,10 \%$ & $93.7 / 1$ & {$[61]$} \\
\hline & & II & Methanol & $4.5: 1-7.5: 1$ & $\mathrm{KOH} / 0.5-1$ & 60 & $7.5: 1,1 \%$ & $92.6 / 1$ & \\
\hline \multirow{2}{*}{ Chicken fat } & Flask,/Magnetic, - & I & Methanol & $10: 1-40: 1$ & $\mathrm{H}_{2} \mathrm{SO}_{4} / 3-35$ & 60 & $40: 1,20 \%$ & $89.6 / 1.33$ & [40] \\
\hline & & II & Methanol & $6: 1$ & $\mathrm{KOH} / 1$ & 60 & & $87.4 / 4$ & \\
\hline \multirow[t]{2}{*}{ Chicken fat } & Flask,/Magnetic, - & I & Methanol & $40: 1$ & $\mathrm{H}_{2} \mathrm{SO}_{4} / 20$ & 60 & & $95 / 1.33$ & [41] \\
\hline & & II & Methanol & $6: 1$ & $\mathrm{KOH} / 1$ & 25 and 60 & $60{ }^{\circ} \mathrm{C}$ & $87.5 / 4$ & \\
\hline \multirow[t]{2}{*}{ Pork fat } & Flask, 1000/Magnetic, - & I & Methanol & $6: 1$ & $\mathrm{H}_{2} \mathrm{SO}_{4} / 1-4$ & $4-65$ & $2 \%, 65{ }^{\circ} \mathrm{C}$ & $56.5 / 5$ & [37] \\
\hline & & II & Methanol & $6: 1$ & $\mathrm{NaOH} / 1$ & 65 & & $66.2 /-$ & \\
\hline \multirow{2}{*}{$\begin{array}{l}\text { Mixture of pig } \\
\text { fat and waste } \\
\text { oil }\end{array}$} & Flask & I & Methanol & & $\mathrm{H}_{2} \mathrm{SO}_{4} / 1.5 \mathrm{~mL}$ & $55-65$ & & & {$[62]$} \\
\hline & & II & Methanol & $25-50 \mathrm{vol} \%$ & $\mathrm{NaOH} / 0.3-0.9$ & & $\begin{array}{l}40 \text { vol\%, } \\
0.3,65^{\circ} \mathrm{C}\end{array}$ & $80 / 1.5$ & \\
\hline \multirow[t]{4}{*}{ Tallow } & Flask, -/Magnetic, - & I & Methanol & $6: 1$ & $\mathrm{KOH} / 1.5$ & $50-55$ & & $98.9 / 1$ & [51] \\
\hline & & II & Methanol & $70: 1$ & $\mathrm{HCl} / 1 \mathrm{~mL} / \mathrm{g}$ & $60-65$ & & $98.3 / 0.5$ & \\
\hline & & & & $72: 1$ & $\mathrm{BF}_{3} / 1 \mathrm{~mL} / \mathrm{g}$ & $60-65$ & & $97 / 0.5$ & \\
\hline & & & & $15: 1$ & $\mathrm{H}_{2} \mathrm{SO}_{4} / 1 \mathrm{~mL} / \mathrm{g}$ & $60-65$ & & $95.3 / 2$ & \\
\hline \multirow[t]{4}{*}{ Tallow } & Flask, -/Magnetic, - & I & Methanol & $63: 1$ & $\mathrm{H}_{2} \mathrm{SO}_{4} /-$ & $60-65$ & & $96.9 / 1$ & [51] \\
\hline & & II & Methanol & & $\mathrm{KOH} / 1.4-2$ & $50-60$ & $1.5 \%$ & $93.1 / 1$ & \\
\hline & & $\mathrm{I}$ & Methanol & $65: 1$ & $\mathrm{HCl} /-$ & $60-65$ & & $98.5 / 1$ & \\
\hline & & II & Methanol & & $\mathrm{NaOCH}_{3} / 1.4-2$ & $50-60$ & $2 \%$ & $94.3 / 1$ & \\
\hline \multirow[t]{2}{*}{ Yellow grease } & Flask, 1000/- & I & Methanol & $7.4: 1-40: 1$ & $\mathrm{H}_{2} \mathrm{SO}_{4} / 5-10$ & 60 & $\begin{array}{l}20: 1,10 \% \\
60{ }^{\circ} \mathrm{C}\end{array}$ & $-/ 1$ & {$[15]$} \\
\hline & & II & Methanol & $6: 1-35: 1$ & $\mathrm{NaOCH}_{3} / 0.35$ & room & $6: 1,0.35 \%$ & $80.5 / 8$ & \\
\hline \multirow[t]{2}{*}{ Brown grease } & Flask, 1000/- & I & Methanol & $7.4: 1-40: 1$ & $\mathrm{H}_{2} \mathrm{SO}_{4} / 5-10$ & 60 & $\begin{array}{l}20: 1,10 \% \\
60^{\circ} \mathrm{C}\end{array}$ & $-/ 1$ & {$[15]$} \\
\hline & & II & Methanol & $6: 1-35: 1$ & $\begin{array}{l}\mathrm{NaOCH}_{3} / 0.21- \\
0.41\end{array}$ & room & $6: 1,0.21 \%$ & $75.1 / 8$ & \\
\hline \multicolumn{10}{|c|}{ Heterogeneous catalysis } \\
\hline \multirow[t]{2}{*}{$\begin{array}{l}\text { Yellow and } \\
\text { brown greases }\end{array}$} & Flask, 25/Mechanical, -Vial, 4 & I & Methanol & & $\begin{array}{l}\text { Diarylammonium/ } \\
0.68 \mathrm{mmol} / \mathrm{g}\end{array}$ & 90 & & $50.6 / 2$ & [63] \\
\hline & & II & Methanol & & $\mathrm{NaOCH}_{3} / 0.3$ & 50 & & $98.1 / 2$ & \\
\hline
\end{tabular}

The types of raw fat materials affect the ester yield. Bhatti et al. [36] showed that the higher FAME yield could be achieved using chicken instead of mutton fat at the same operating conditions. Using three different feedstocks (tallow, lard and poultry fat), Mata et al. [33] showed that it was possible to produce biodiesel with yield above $90 \%$ at the same operating conditions, except in the case of chicken fat (77\% ester yield). Biodiesel marked B100 (100\% biodiesel) from these feedstocks cannot be used in vehicle engines without further additives introduction.

Da Chunha et al. [32] performed the biodiesel production with high yield (96\%) from beef tallow on large-scale in a continuous pilot plant with the further aim of construction of an industrialscale plant $(120,000 \mathrm{~kg} /$ day capacity). However, it was necessary to introduce the methanol recovery from glycerol and biodiesel phases and the biodiesel separation from obtained mixture, which required two additional steps and increased production costs.

4.1.1.2. Acid catalysis. Compared to the base catalyzed process, the use of acid catalysts in the transesterification processes of WAFs needs much longer reaction time and higher alcohol:oil molar ratio $[36,47,55]$. Bhatti et al. [36] showed that the higher ester yield from WAFs could be achieved using acid instead of base catalyst. The most

used acid catalyst and type of alcohol in these processes are sulfuric acid and methanol (Table 3). Absolute ethanol was found to be better than absolute methanol for processing restaurants fat to biodiesel due to lower viscosity. In this case, the maximum conversion of $78 \%$ was achieved [30]. Also, the higher alcohol concentrations resulted in the higher reaction rate [47].

The catalyst quantity influences the biodiesel yield. With increasing concentration of catalyst, FAME yield firstly increases up to the maximum value and subsequently decreases, independently of fat origin and reaction temperature [36,47]. Bhatti et al. [36] believe that the reversible nature of transesterification reaction is the main reason for this behavior.

The type of acid catalyst has a major influence on conversion degree of TAGs in raw material. Montefrio et al. [55] optimized the reaction conditions for the esterification of trap grease as feedstock using homogeneous and heterogeneous acid catalysts and recommended sulfuric acid as a more efficient catalyst than $\mathrm{Fe}_{2}\left(\mathrm{SO}_{4}\right)_{3}$ under the same reaction conditions.

\subsubsection{Two-step (acid/base) processes}

Two-step (acid/base) processes for biodiesel production consist of acid-catalyzed FFA esterification (pre-treatment, first step) for 
reducing the FFAs in WAFs below $0.5 \%$ [56], or to less than $2 \mathrm{mg}$ $\mathrm{KOH} / \mathrm{g}$ [58,59], and the base-catalyzed TAG transesterification (second step). This is very promising way to take advantages of both base and acid catalysts, to overcome slow reaction problem, to eliminate the soap formation and to achieve high ester yield at mild reaction conditions, compared to one-step processes. The higher production cost is the only disadvantage of the two-step processes, compared to the one-step processes.

A review of two-step processes for biodiesel production from different WAFs is presented in Table 5. Important variables which affect the acid value in the first step and the ester yield in the second step are type of feedstock, type and catalyst concentration, alcohol:oil molar ratio, reaction temperature and reaction time.

In order to determine the effect of raw material in esterification process and to compare the efficacy of acid catalyst, Encinar et al. [47] investigated three types of fats with different FFA contents. Regardless of FFA content of the fats, the initial reaction rate was high and decreased over time. But, when the FFA content was higher, the reaction was faster. This occurs because the esterification reaction is a chemical equilibrium where FFAs are a reagent [47].

Mainly, sulfuric acid in the first step and $\mathrm{KOH}$, rarely $\mathrm{NaOH}$ and $\mathrm{NaOCH}_{3}$, in the second transesterification step were used. Sulfamic [40] and phosphoric [47] acid are poor catalysts, as they do not reduce acid value of the fat significantly. The catalyst amount is a very important factor which affects the product quality. The required amounts of acid and base catalysts varied from $0.5 \%$ to $20 \%$ and $0.4 \%$ to $1 \%$, respectively. Most researchers [17,40,47,61] concluded that after addition mixture of acid catalyst and alcohol into heated fat, the initial FFA content decreased and then stayed constant. According to Encinar et al. [47], the catalyst migration into the accumulated water was the main reason for such a variation, becoming unavailable for the reaction. In the second step of the process, the increase of base catalyst to the optimum value increased the ester yield firstly, and then a slight decrease of ester yield was observed due of soap formation $[17,47,60,61]$.

Methanol is the commonly used alcohol in both steps of transesterification of WAFs. The optimum molar ratio of methanol:fat was in the range of $6: 1$ to $40: 1$. With increasing methanol:fat molar ratio in the first step, the acid value decreased to the optimum level $[40,47,61]$, because excess of methanol, keeping the acid catalyst in the methanol phase, promoted the completion of the reaction [47]. The increase of methanol:esterified fat molar ratio in the second step leads to the increase of ester yield to the optimum value, which remains the same more or less with further increasing the molar ratio [60-62]. This is attributed to the slightly recombination of esters and glycerol to MAGs in the excess of methanol [47].

Most researchers have conducted both steps at temperatures close to the boiling point of methanol, i.e. in the range of $60-65{ }^{\circ} \mathrm{C}$ (Table 5), and the maximum ester yields were obtained. The increase of reaction temperature decreased the acid value during the reaction time in the first step of the process [37,47]. After pretreatment process, the ester yield increased with the increasing of reaction temperature from $25^{\circ} \mathrm{C}$ to $60{ }^{\circ} \mathrm{C}$ [40]. In this case, the ester yield did not change significantly with increasing reaction time. Görö et al. [60] showed that the reaction could not start and glycerol could not be formed if the temperature in the second step was adjusted at $50{ }^{\circ} \mathrm{C}$. The temperatures in the range from 62 to $70{ }^{\circ} \mathrm{C}$ caused evaporation of methanol and reduced the overall ester yield [60].

Fröhlich et al. [51] investigated two methods in order to prevent yield losses which were caused by the dissolution of FAME in the glycerol phase. These involved esterification of FFAs in low-grade tallow either before or after base-catalyzed methanolysis aiming at biodiesel-grade esters production. In these relatively simple processes, a very good conversion was obtained. However, base-catalyzed transesterification followed by acid- catalyzed esterification of FFAs achieved almost theoretical yields (about 98\%). Because of the relatively large amounts of reagents needed for neutralization when transesterification was carried out first, FFA esterification as the first step was a more convenient process for large scale conversion of FFAs present at a high level. Also, Fröhlich et al. [51] compared the one-step base-catalyzed transesterification with both two step processes using the same raw material, and it was observed a much lower ester yield in the former case.

\subsection{Heterogeneously catalyzed processes}

In recent years, most researchers are more interested in the use of heterogeneous than homogeneous catalysts in the biodiesel synthesis because of simple product separation and purification, possibility of their regeneration and reuse, less energy requirement and improved product quality. However, the major drawbacks of using heterogeneous catalysts generally lie in their preparation, a need for high selectivity for the desired product formation and difficulty in reusing in some cases [64]. Also, unlike the homogeneously catalyzed processes, heterogeneous catalytic transesterification reactions are commonly performed with alcohol:fat molar ratios higher than 6:1, catalyst concentration of 2$20 \%$, reaction temperature close to or much higher than ambient and long reaction time even to $18 \mathrm{~h}$ [43]. These processes can be performed in one and two steps, using various compounds as solid catalysts.

\subsubsection{One-step processes}

Table 6 gives an overview on the catalyst types and the reaction conditions used in heterogeneously catalyzed one-step processes of biodiesel production from WAFs.

The optimum reaction conditions for biodiesel production from WAFs depend on the raw material and the catalyst applied. Different basic, acidic or mixed solid materials are used as catalyst. Among them are metal hydroxides, oxides and complexes, such as calcium, magnesium or zirconium oxide, zeolites, hydrotalcites and supported catalysts [72]. The most important factor influencing the type of appropriate heterogeneous catalyst is FFA content in the WAF. Generally, WAFs with a lower FFA content are subjected to base-catalyzed processes $[43,65]$, while acid solid catalysts are used for FAME synthesis from WAFs with a high FFA content ( > 5\%) $[63,68,69,71]$.

4.2.1.1. Base catalysis. Two research groups [66,67] achieved different conversions of the same feedstock (poultry fat) using two different base catalysts. In the study by Liu et al. [67], the use of solid catalyst derived from $\mathrm{Mg}-\mathrm{Al}$ hydrotalcite enabled a conversion higher than $90 \%$ under relatively extreme conditions: high reaction temperature $\left(120^{\circ} \mathrm{C}\right)$, methanol:fat molar ratio (30:1), catalyst concentration (10\%) and long reaction time (8 h). However, Reddy et al. [66] achieved 100\% conversion using nanocrystalline calcium oxide at ambient temperature (23$25^{\circ} \mathrm{C}$ ), very large methanol:fat molar ratio (70:1), low catalyst concentration (1\%) and reaction time of $6 \mathrm{~h}$.

Preparation of basic catalysts is very important factor influencing the efficiency of heterogeneously catalyzed reaction and could be carried out in different ways. The wet impregnation method involved the addition of aqueous solution of $\mathrm{KOH}$ over $\mathrm{MgO}$ [65] or $\mathrm{Al}_{2} \mathrm{O}_{3}$ [54], followed by calcination of the impregnated catalyst at a high temperature. Crystal nanonization is an efficient technique for preparing catalysts even at room temperature due to reactivity and increased surface area of nanosized oxides [66]. Mixed oxides, obtained by the calcination of hydrotalcites, showed high surface areas and large pore volumes [67]. 
Table 6

A review of the heterogeneous one-step transesterification processes of different WAFs.

\begin{tabular}{|c|c|c|c|c|c|c|c|c|}
\hline \multirow{2}{*}{$\begin{array}{l}\text { Type of } \\
\text { animal fat }\end{array}$} & \multirow{2}{*}{$\begin{array}{l}\text { Type, volume of } \\
\text { reactor, } \mathrm{cm}^{3} / \text { type } \\
\text { of agitator, } \\
\text { agitation } \\
\text { intensity, rpm }\end{array}$} & \multirow{2}{*}{$\begin{array}{l}\text { Type of } \\
\text { e alcohol }\end{array}$} & \multirow{2}{*}{$\begin{array}{l}\text { Alcohol:fat molar } \\
\text { ratio, } \mathrm{mol} / \mathrm{mol}\end{array}$} & \multirow[t]{2}{*}{ Catalyst/loading, wt\% to the fat } & \multirow{2}{*}{$\begin{array}{l}\text { Temperature, } \\
{ }^{\circ} \mathrm{C}\end{array}$} & \multicolumn{2}{|c|}{ Optimal reaction conditions } & \multirow[t]{2}{*}{ Reference } \\
\hline & & & & & & $\begin{array}{l}\text { Reaction } \\
\text { conditions }\end{array}$ & $\begin{array}{l}\text { Yield } \\
\text { (Conversion), } \\
\text { \%/Time, h }\end{array}$ & \\
\hline \multicolumn{9}{|c|}{ Base catalysis } \\
\hline \multirow[t]{2}{*}{ Catfish fat } & & Methanol & $10: 1-14: 1$ & $\mathrm{KOH} / \gamma-\mathrm{Al}_{2} \mathrm{O}_{3} / 5-8$ & 60 & $8: 1,6 \%$ & $92.6 / 1.5$ & \multirow[t]{2}{*}[54]{} \\
\hline & & Methanol & $10: 1-14: 1$ & $\mathrm{KOH} / \gamma-\mathrm{Al}_{2} \mathrm{O}_{3} / 5-8$ & 51 & $12: 1,6 \%$ & $92.3^{\mathrm{a}} / 0.33$ & \\
\hline Pork lard & $\begin{array}{l}\text { Flask, 250/ } \\
\text { Magnetic, - }\end{array}$ & Methanol & $6: 1-24-24: 1$ & $\mathrm{CaMnO}_{x}, \mathrm{CaO} / 0.6-4$ & $60-70$ & $\begin{array}{l}18: 1 \mathrm{CaMnO}_{x}, 3 \% \\
60{ }^{\circ} \mathrm{C}\end{array}$ & $92.4 / 4$ & [43] \\
\hline Pork lard & $\begin{array}{l}\text { Flask, 250/ } \\
\text { Magnetic, - }\end{array}$ & Methanol & $18: 1$ & $\mathrm{CaMnO}_{x} / 3$ & 50 & & $92.5 / 8$ & {$[38]$} \\
\hline Mutton fat & & Methanol & $11: 1-22: 1$ & $\mathrm{MgO}-\mathrm{KOH}-X(X=5-20)^{\mathrm{b}} / 1.5-4$ & $45-65$ & $\begin{array}{l}22: 1, \mathrm{MgO}-\mathrm{KOH}- \\
20,4 \%, 65^{\circ} \mathrm{C}\end{array}$ & $98 / 0.33$ & {$[65]$} \\
\hline \multirow{3}{*}{$\begin{array}{l}\text { Poultry fat } \\
\text { Poultry fat }\end{array}$} & \multirow{3}{*}{$\begin{array}{l}\text { Batch reactor, } \\
-/-, 1417\end{array}$} & Methanol & $10 \mathrm{~cm}^{3}: 3 \mathrm{~g}$ & Nanocrystalline $\mathrm{CaO} / 1 \mathrm{mmol}$ & $23-25$ & $\approx 1 \%, 70: 1$ & $(100) / 6$ & {$[66]$} \\
\hline & & Methanol & $6: 1-60-60: 1$ & $\mathrm{Mg}_{6} \mathrm{Al}_{2}\left(\mathrm{CO}_{3}\right)(\mathrm{OH})_{16} 4 \mathrm{H}_{2} \mathrm{O} / 10-20$ & \multirow[t]{2}{*}{$60-120$} & $\begin{array}{l}30: 1,10 \%, 120^{\circ} \mathrm{C}, \\
6.8 \text { atm }\end{array}$ & $(93) / 8$ & \multirow[t]{2}{*}[67]{} \\
\hline & & Methanol & $6: 1-60-60: 1$ & $\begin{array}{l}\mathrm{Mg}_{6} \mathrm{Al}_{2}\left(\mathrm{CO}_{3}\right)(\mathrm{OH})_{16} 4 \mathrm{H}_{2} \mathrm{O} / 4 \mathrm{~g} / \\
\mathrm{cm}^{3}\end{array}$ & & $\begin{array}{l}30: 1,120^{\circ} \mathrm{C} \\
6.8 \mathrm{~atm}\end{array}$ & $(70)^{c / 8}$ & \\
\hline \multicolumn{9}{|c|}{ Acid catalysis } \\
\hline $\begin{array}{l}\text { Brown } \\
\text { grease }\end{array}$ & Vial, 4/- & Methanol & $15: 1$ & $\begin{array}{l}\text { Mesoporous silica } \\
\text { diphenylammonium triflate } / 15^{\mathrm{d}}\end{array}$ & 95 & & $(98) / 2$ & [63] \\
\hline $\begin{array}{l}\text { Brown } \\
\text { grease }\end{array}$ & $\begin{array}{l}\text { Batch reactor, } \\
45 /-\end{array}$ & Methanol & $10.5: 15^{\mathrm{e}}$ & $\mathrm{ZnO} / \mathrm{ZrO}_{2} / 0.8 \mathrm{~g}$ & 200 & $\begin{array}{l}\text { Autogenous } \\
\text { pressure }\end{array}$ & $78 / 2$ & [68] \\
\hline Lard & $\begin{array}{l}\text { Batch reactor, } \\
250 / \text { magnetic, } \\
300\end{array}$ & Methanol & $4: 1$ & Amberlyst 70/1.25-10 & 65 & $10 \%$ & $(\approx 95) / 6$ & [69] \\
\hline $\begin{array}{l}\text { Beef } \\
\text { tallow }\end{array}$ & $\begin{array}{l}\text { Flask, 100/ } \\
\text { magnetic, - }\end{array}$ & Ethanol & $100: 1$ & Sulfonated polystyrene/20 mol\% & 64 & & $(75) / 18$ & {$[70]$} \\
\hline Fat & Autoclave, 25/ & Methanol & $45.8: 1$ & Zr-SBA-15/12.45 & 209 & & $90 / 6$ & [71] \\
\hline Lard & mechanical, - & & & & & & $95 / 6$ & \\
\hline $\begin{array}{l}\text { Mixture of } \\
\text { fats }\end{array}$ & & & & & & & $92 / 6$ & \\
\hline
\end{tabular}

Also, the decrease of $\mathrm{MgO}$ catalyst amount impregnated with $\mathrm{KOH}$ resulted in an increase in the time needed for finishing the reaction [65]. Further, when the catalyst concentration increased, the biodiesel yield increased, also [43,54,65]. However, after certain catalyst concentration, a decrease in the biodiesel yield was observed [54].

Liu et al. [67] showed that Mg-Al mixed oxide were thermally and mechanically stable, and no significant difference was observed in particle size and morphology of the used catalyst. The similar $\mathrm{Mg}-\mathrm{Al}$ ratio of the fresh and used catalyst also confirmed that the catalyst did not leach in the reaction mixture of poultry fat and methanol.

Some authors showed that the solid catalyst could be reused $[43,66]$. However, nanocrystalline $\mathrm{CaO}$ can be successfully recycled only three times as it failed in the fourth cycle [66].

As would be expected, reaction temperature positively impacted TAG conversion in raw fat materials. Increasing temperature not only led to faster reaction kinetics, but also improved phase miscibility [67]. For instance, Liu et al. [67] showed that about $2 \mathrm{~h}$ was needed at $120^{\circ} \mathrm{C}$ to achieve $60 \%$ conversion of TAGs from poultry fat using methanol and mixed $\mathrm{Mg}-\mathrm{Al}$ oxide, whereas at $90{ }^{\circ} \mathrm{C}$ longer than $8 \mathrm{~h}$ was required. According to Dias et al. [43], the reaction progressed much faster at $60{ }^{\circ} \mathrm{C}$ than at $50{ }^{\circ} \mathrm{C}$ and $40{ }^{\circ} \mathrm{C}$; after $4 \mathrm{~h}$, the maximum ester yield was $92.4 \%$, compared to 95.8\% achieved within $8 \mathrm{~h}$. However, the use of higher reaction temperature increased the process costs because of higher energy consumption and higher system pressure to keep methanol in the liquid phase. For example, Liu et al. [67] estimated a doubling in equipment costs by increasing the reaction temperature from $120{ }^{\circ} \mathrm{C}$ to $170{ }^{\circ} \mathrm{C}$.
The alcohol:fat molar ratio is the another important factor in transesterification reaction of WAFs using heterogeneous catalysts, and generally it is higher (18:1 [43] and 30:1 [67]) than that applied in the case of using homogeneous catalysts. According to Liu et al. [67], for a given reaction time of $2 \mathrm{~h}$, the poultry fat conversion steadily increased from $23 \%$ to $75 \%$ as the molar ratio of reactants increased from 6:1 to 60:1. A larger excess of methanol leads the TAG conversion to a greater degree from standpoint of thermodynamics. With $91 \%$ poultry fat converted, the ester yield was $8 \%$ lower using the molar ratio of $6: 1$ instead of $60: 1$. However, the use of a large excess of methanol may not be the most efficient way to increase glycerol selectivity [67]. The results of Dias et al. [43] indicated that an increase in the methanol:fat molar ratio had no effect on biodiesel production when lower temperature $\left(40{ }^{\circ} \mathrm{C}\right)$ and a higher catalyst concentration (5\%) were used. As temperature increased $\left(50{ }^{\circ} \mathrm{C}\right)$ and catalyst amount decreased (3\%), the effect became positive and an increase in the molar ratio significantly increased ester yield. Mutreja et al. [65] confirmed the increase of ester yield with increasing the molar ratio but after certain methanol amount there was no effect on the ester yield.

The results of Mutreja et al. [65] showed that $\mathrm{KOH}$-impregnated $\mathrm{MgO}$ was effective in transesterification of mutton fat even in the presence of additional $1 \%$ of the FFAs (palmitic acid/oleic acid) or water content.

4.2.1.2. Acid catalysis. Ngo et al. [63] and Kim et al. [68] used diarylammonium salts supported onto silica SBA 15 and $\mathrm{ZrO}_{2}$ supported metal oxides, respectively, to obtain biodiesel from 
brown greases with a high FFA content (40\% and 87\%, respectively). Using the mentioned highly effective solid catalyst for esterification of FFAs from greases, Ngo et al. [63] showed that it was possible to reduce FFA content to below $1 \%$ under mild reaction conditions and to achieve a high conversion. However, this catalyst displayed minimal transesterification activity and should be further tested. Due to high water and sulfur concentrations in raw fat material, Kim et al. [68] recommended simultaneous realization of desulfurization and de-metallization through esterification in order to achieve a good ester yield. The long-term activity of the $\mathrm{ZnO} / \mathrm{ZrO}_{2}$ catalyst was also confirmed in a continuous packed-bed reactor for esterification of $90 \%$ technical grade oleic acid which helped as a model for brown grease [68]. The ester yield remained over $97 \%$ for 60 days. For pretreatment of lard, Bianchi et al. [69] and Melero et al. [71] used strongly acidic cation exchanger Amberlyst (A70) and zirconium-containing SBA-15 silica (Zr-SBA-15), respectively. Melero et al. [71] showed that $\mathrm{Zr}$-SBA-15 catalyst is highly active in the simultaneous esterification of FFAs and transesterification of TAGs from lowgrade WAFs with methanol, independently of their acid value or unsaponifiable matter content.

Soldi et al. [70] carried out ethanolysis of beef tallow using Amberlyst 15 as catalyst but no ethyl esters were formed. When methanol was used for reaction, this resin led to a $13 \%$ conversion only. The linear sulfonated polystyrene, obtained from disposable plastic materials, was more efficient for the production of ethyl esters from beef tallow and provided not only a good way to reduce costs but also to improve the sustainability of biodiesel production.

Bianchi et al. [69] showed that the increase of reaction temperature and catalyst concentration increased the catalyst activity. High FFA conversions were observed even at $30{ }^{\circ} \mathrm{C}$ and with low solid concentration (1.25\%).

Comparing two type acid catalysts, sulfuric acid and $\mathrm{Fe}_{2}\left(\mathrm{SO}_{4}\right)_{3}$, for the esterification of trap grease under the same reaction conditions, Montefrio et al. [55] recommended sulfuric acid as a more efficient, despite some advantages of $\mathrm{Fe}_{2}\left(\mathrm{SO}_{4}\right)_{3}$ such as insolubility in methanol and grease, easily use and recovery and possibility of reduction for equipment corrosion. Also, they showed that the efficiency of esterification increased with mixing intensity, and this increase was much higher in the presence of $\mathrm{H}_{2} \mathrm{SO}_{4}$ than in the presence of $\mathrm{Fe}_{2}\left(\mathrm{SO}_{4}\right)_{3}$.

Dias et al. [38] used different catalyst, two heterogeneous (calcium manganese oxide and $\mathrm{CaO}$ ) and one homogeneous $(\mathrm{NaOH})$, aiming at production of biodiesel with similar purity (higher than 92\%) from pork lard. The reaction rate of the heterogeneous catalysis could not compete with the homogeneous one. After $15 \mathrm{~min}$ of reaction, the maximum ester yield was obtained using $\mathrm{NaOH}$ as catalyst. When the solid catalysts used in the reaction, it was shown that $\mathrm{CaO}$ gave higher reaction rate within $4 \mathrm{~h}$ of reaction, while calcium manganese oxide was less active. After $8 \mathrm{~h}$ of reaction, the achieved ester yield was similar independently of the catalyst type. However, the reusability and lower activation temperature of the mixed-calcium manganese oxide could be advantages in its use. Therefore, it was identified as an interesting solid catalyst for biodiesel production from pork lard. Also, using different raw materials (pork lard, waste frying oil and mixture of waste frying oil and lard) in the esterification reaction with calcium manganese oxide, Dias et al. [38] obtained the slowest rate when lard was used for biodiesel synthesis. This was attributed to the higher viscosity of the lard and more difficult contact in the three phase system (methanol/catalyst/TAGs).

\subsubsection{Two-step (acid/base) processes}

Only Ngo et al. [21] studied the two-step transesterification of WAFs using heterogeneous catalyst (Table 5). The authors investigated methanolysis of yellow and brown greases. Because of a high FFAs content, it is difficult to obtain a very high ester yield from these WAFs using base catalysts. A series of diarylammonium catalyst was used as highly effective catalyst for the esterification of FFAs present in greases. A very high conversion of FFAs to esters (95-99\%) was obtained with a low catalyst loading (2-3 mol\%). Also, the same authors incorporated the solid catalysts into insoluble porous polymers via free radical-initiated polymerization and showed that the polymer-immobilized catalysts (diphenylammonium triflate) were equally effective as their homogeneous counterparts in esterifying FFAs to esters and were readily recycled and reused three cycles for esterification upon reactivation with triflic acid. The resulting ester-acylglycerol mixture was then readily converted to total esters by the basecatalyzed transesterification. In this way, the two-step process provided an efficient method for the biodiesel production from greases. However, when the reactivated catalyst was used for the fourth time under similar reaction conditions, a significant drop in the esterification activity was observed.

\subsection{Enzyme-catalyzed processes}

Enzymatic catalysts have a high catalytic activity in water-poor media, and can simultaneously catalyze TAG alcoholysis and FFA esterification and have been often used in transesterification reaction of WAFs. Lipases are preferable used enzymes in transesterification reaction of WAFs. The main disadvantage of lipasescatalyzed processes, their high cost, can be reduced by enzyme immobilization, which enables the reuse and easy recovery of the enzyme. Support material and immobilization strategy are the most important factors to attain active and stable immobilized derivates. Da Rós et al. [73] used two different non-commercial supports to immobilize lipase from Burkholderia cepacia, such as inorganic matrix (niobium oxide, $\mathrm{Nb}_{2} \mathrm{O}_{5}$ ) and a hybrid matrix (polysiloxane-polyvinyl alcohol $\mathrm{SiO}_{2}-\mathrm{PVA}$ ), by covalent binding for ethanolysis of beef tallow. Very different yields for the same reaction times were obtained. Immobilized lipase on $\mathrm{SiO}_{2}-\mathrm{PVA}$ was approximately 2 times more stable than the immobilized derivate on $\mathrm{Nb}_{2} \mathrm{O}_{5}$ and 17 times more stable than the free lipase.

The immobilized lipases from different origins, such as Candida antractica [19,39], Mucor miehei [74] and Burkholderia cepacia [73], are most frequently used in transesterification reactions of WAFs. Generally, enzyme-catalyzed reactions are performed with a high lipase amount (about 4-20\%). The ester yield increases rapidly with increasing the amount of lipase up to $20 \%(\mathrm{w} / \mathrm{w})$ but increases slowly above this amount [75]. To explore the possibility of synergistic effect, Huang et al. [39] applied two lipases with their optimum amounts for the transesterification of lard. The highest ester yield of $93.5 \%$ was achieved when the combined proportion of lipases (non-specific Novozym 435 and 1,3 specific Lipozyme TLIM) was 0.6 , and it was higher than those obtained by single lipases.

Immobilized lipases can be used repeatedly over an extended period of time. Lu et al. [75] performed the lard methanolysis over seven repeated cycles with no significant decrease in the lipase activity, and FAME yield was higher than 80\%. The sharply decrease of ester yield in the eighth cycle indicated that the lipase was not suitable for further reaction. Also, two immobilized lipases (Novozym 435 and Lipozyme TLIM) were regenerated by washing with organic solvent after each cycle and could be continuously successfully reused for 20 cycles nearly without any loss of the activity [39]. Combined use of these two lipases is a potential way to reduce the cost of enzyme-catalyzed biodiesel production from lard using methanol as acyl acceptor and tert-butanol as the reaction medium [39]. 
Table 7

A review of the reaction conditions of the lipase-catalyzed transesterification processes of different WAFs.

\begin{tabular}{|c|c|c|c|c|c|c|c|c|c|c|c|}
\hline \multirow{2}{*}{$\begin{array}{l}\text { Type of } \\
\text { animal fat }\end{array}$} & \multirow{2}{*}{$\begin{array}{l}\text { Type, volume of } \\
\text { reactor, } \mathrm{cm}^{3} / \text { type of } \\
\text { agitator, agitation } \\
\text { intensity, rpm }\end{array}$} & \multirow{2}{*}{$\begin{array}{l}\text { Type of } \\
\text { alcohol }\end{array}$} & \multirow{2}{*}{$\begin{array}{l}\text { Alcohol: } \\
\text { fat molar } \\
\text { ratio, mol/ } \\
\text { mol }\end{array}$} & \multirow{2}{*}{$\begin{array}{l}\text { Lipase source } \\
\text { (Enzyme commercial } \\
\text { name) }\end{array}$} & \multirow{2}{*}{$\begin{array}{l}\text { Lipase } \\
\text { loading, } \\
\text { wt\% to } \\
\text { the fat }\end{array}$} & \multirow{2}{*}{$\begin{array}{l}\text { Temperature, } \\
{ }^{\circ} \mathrm{C}\end{array}$} & \multirow[t]{2}{*}{ Solvent } & \multirow{2}{*}{$\begin{array}{l}\text { Water, } \\
\text { wt\% to } \\
\text { the fat }\end{array}$} & \multicolumn{2}{|c|}{ Optimal reaction conditions } & \multirow[t]{2}{*}{ Reference } \\
\hline & & & & & & & & & $\begin{array}{l}\text { Reaction } \\
\text { conditions }\end{array}$ & $\begin{array}{l}\text { Yield } \\
\text { (Conversion), } \\
\text { \%/Time, h }\end{array}$ & \\
\hline Lard & $\begin{array}{l}\text { Screw-cap vial,-/ } \\
\text { Magnetic, } 200\end{array}$ & Methanol & $1: 1$ & $\begin{array}{l}\text { Candida antractica } \\
\text { (Chirazyme L-2) }\end{array}$ & 10 & 30 & & & & $(74) / 72$ & {$[19]$} \\
\hline Lard & $\begin{array}{l}\text { Flask, -/ Reciprocal } \\
\text { shaking, } 180\end{array}$ & Methanol & $3: 1$ & Candida sp. 99-125 & 20 & $40-60$ & $\begin{array}{l}n- \\
\text { hexane }\end{array}$ & $0-50$ & $40{ }^{\circ} \mathrm{C}, 20 \%$ & $87.4 / 30$ & {$[75]$} \\
\hline Lard & $\begin{array}{l}\text { Flask, -/ Reciprocal } \\
\text { shaking }\end{array}$ & Methanol & $3: 1-7: 1$ & $\begin{array}{l}\text { C. antarctica } \\
\text { (Novozym 435) with } \\
\text { T. lanuginosus } \\
\text { (Lipozyme TLIM) }\end{array}$ & $2-6$ & 50 & $\begin{array}{l}t- \\
\text { butanol }\end{array}$ & & $5.12: 1,4$ & $97.2 / 20$ & [39] \\
\hline $\begin{array}{l}\text { Beef } \\
\text { tallow }\end{array}$ & $\begin{array}{l}\text { Reactor, 25/ } \\
\text { Magnetic, } 150\end{array}$ & Ethanol & $12: 1$ & $\begin{array}{l}\text { Burkholderia cepacia } \\
\text { (Lipase PS) }\end{array}$ & 20 & 50 & & & & $\begin{array}{l}89.7^{\mathrm{a}} / 48 \\
40.2^{\mathrm{b}} / 48\end{array}$ & [73] \\
\hline $\begin{array}{l}\text { Beef } \\
\text { tallow }\end{array}$ & & Ethanol & $6: 1$ & Burkholderia cepacia & & 50 & & & & $(100)^{c} / 8$ & {$[76]$} \\
\hline $\begin{array}{l}\text { Rendered } \\
\text { animal } \\
\text { fat }\end{array}$ & Vial, 30/Shaking, 60 & Ethanol & $1: 1-6: 1$ & $\begin{array}{l}\text { Mucor meihei } \\
\text { (Lipozyme-IM) }\end{array}$ & $21.7 \mathrm{U}$ & $25-65$ & & & $4: 1,35^{\circ} \mathrm{C}$ & $27 / 120$ & {$[74]$} \\
\hline
\end{tabular}

a Lipase immobilized on $\mathrm{Nb}_{2} \mathrm{O}_{5}$.

${ }^{\mathrm{b}}$ Lipase immobilized on $\mathrm{SiO}_{2}$-PVA.

${ }^{\mathrm{c}}$ Use of microwave irradiation $(8-15 \mathrm{~W})$.

The review of the reaction conditions of the lipase-catalyzed alcoholysis of WAFs is given in Table 7. The optimum temperature for enzymatic WAF transesterification lies in the range between 30 and $50{ }^{\circ} \mathrm{C}[19,39,73-75]$. When the temperature is higher than optimum, a denaturation of enzyme occurs, leads to the loss of solvents through volatilization [75] and the product amount decreases [74]. The lipase catalytic activity and stability influences the FAME yield and depends on the water content. The ester yield decreased sharply when the water content was more than $30 \%$ because of the reduced homogeneity of substrate mixture [75]. However, when the lipase was transferred into a new system with water content of $20 \%$, the ester yield could be as high as $30 \%$ and showed that the lipase did not lose its activity. Several organic solvents are selected due to their suitability in the enzymatic alcoholysis of WAFs [75]. In the methanolysis of lard catalyzed with Candida lipase, the ester yield increases by addition of $n$ hexane in the reaction mixture [75], although the immobilized Candida lipase can also convert lard in a solvent free system [19].

Inactivation of lipases that leads to the decrease of ester yields mostly depends on the concentration of alcohol. This problem can be solved by addition of alcohol in a few steps. Three-step methanolysis enables sufficient conversion of TAGs from lard to high ester yields $[19,75]$. In the first and second step of alcohol addition, the conversions are not high, but in the third step the enzyme-substrate contact is more sufficient due to completely methanol dissolubility in the obtained ester. Also, Lee et al. [19] applied silica gel as porous materials which could keep the lipase active during the reaction when excess methanol was used.

Most frequently used alcohols in enzyme transesterification processes of WAFs are methanol and ethanol. So far, most researchers have used methanol and rarely ethanol for biodiesel production, because methanolysis is faster than ethanolysis. Comparing influence of alcohol type on ester production during three stepwise transesterification reaction Lee et al. [19] obtained higher conversion using methanol. After the third step, conversion to lard methyl and ethylester were $74 \%$ and $43 \%$, respectively.

\subsection{Supercritical processes}

The processing of WAFs aiming at biodiesel production could be conducted by using the non-catalytic synthesis in supercritical alcohols. The main advantages of these processes are faster reaction rate, easy product purification, no need for any pretreatment and the ability of using non-expensive unrefined materials [77]. Also, the presence of water and FFAs do not affect the ester yield because TAG transesterification and FFA esterification occur simultaneously. For example, lard samples from different sources (refined and waste), which contain various FFAs and water contents, were treated successfully using a supercritical process [78]. Obtained esters from waste lard with no pretreatment were found to be comparable with those from using refined lard. Moreover, the biodiesel prepared from waste lard contained a very small amount of FFAs, which met the specifications of EN 14214 and confirmed that the presence of water and FFAs did not affect the ester yield. In this way, the waste lard can be a promising alternative feedstock for biodiesel production via supercritical process. A review on the operating conditions applied in various batch and continuous reactors under supercritical conditions is given in Table 8 .

The supercritical processes of WAFs were carried out at much higher temperatures and pressures compared to the conventional processes and higher than the critical temperature and pressure of methanol $\left(240{ }^{\circ} \mathrm{C}, 8.08 \mathrm{MPa}\right)$ and ethanol $\left(244^{\circ} \mathrm{C}, 6.38 \mathrm{MPa}\right)$. Marulanda et al. $[79,80]$ investigated the effect of reaction conditions (temperature, pressure, alcohol:fat molar ratio and residence time) on TAG conversion from chicken fat and the product quality in two reactors (batch and continuous) under supercritical conditions. The authors applied a preheating step at high temperature $\left(350{ }^{\circ} \mathrm{C}\right)$ without a significant thermal fat decomposition. Also, they concluded that the transesterification was not a reverse reaction at $300-400{ }^{\circ} \mathrm{C}$, and the byproduct (glycerol) was thermally decomposed. The continuous process with moderate excess of methanol and in-situ glycerol decomposition might be very promising for increasing the profitability, in comparison with competitive technologies [80].

The reaction pressure does not significantly affect the efficiency of the biodiesel production at high temperature, but slightly changes the composition of the product [80]. Usually, the high ester yield was obtained at a pressure of 20-40 MPa $[79,80]$. Almost complete TAG conversion was achieved at a pressure of $30 \mathrm{MPa}$ using a tubular reactor [80]. When the methanol:fat molar ratio was increased, a complete conversion was achieved, but the excess methanol was also consumed in other thermal reactions 
Table 8

A review of the reaction conditions of the supercritical transesterification processes of WAFs.

\begin{tabular}{|c|c|c|c|c|c|c|c|c|}
\hline \multirow{2}{*}{$\begin{array}{l}\text { Type of } \\
\text { animal fat }\end{array}$} & \multirow{2}{*}{$\begin{array}{l}\text { Type, volume of reactor, } \\
\mathrm{cm}^{3} / \text { type of agitator, } \\
\text { agitation intensity, rpm }\end{array}$} & \multirow{2}{*}{$\begin{array}{l}\text { Type of } \\
\text { alcohol }\end{array}$} & \multirow{2}{*}{$\begin{array}{l}\text { Alcohol:fat molar } \\
\text { ratio, } \mathrm{mol} / \mathrm{mol}\end{array}$} & \multirow[t]{2}{*}{ Catalyst/loading, wt $\%$ to the fat } & \multirow{2}{*}{$\begin{array}{l}\text { Temperature, } \\
{ }^{\circ} \mathrm{C}\end{array}$} & \multicolumn{2}{|c|}{ Optimal reaction conditions } & \multirow[t]{2}{*}{ Reference } \\
\hline & & & & & & $\begin{array}{l}\text { Reaction } \\
\text { conditions }\end{array}$ & $\begin{array}{l}\text { Yield } \\
\text { (Conversion), } \\
\text { \%/Time, h }\end{array}$ & \\
\hline Chicken fat & Batch, 6.2/- & Methanol & $3: 1-6: 1$ & - & $300-400$ & $\begin{array}{l}6: 1,400^{\circ} \mathrm{C} \\
41.1 \mathrm{MPa}\end{array}$ & $88 / 6$ & [79] \\
\hline Chicken fat & Tubular, 2/- & Methanol & $3: 1-12: 1$ & - & $350-400$ & $\begin{array}{l}9: 1,400{ }^{\circ} \mathrm{C} \\
30 \mathrm{MPa}\end{array}$ & $(\approx 100) / 6^{a}$ & {$[80]$} \\
\hline Lard & $\begin{array}{l}\text { Autoclave, 25/Magnetic, } \\
500\end{array}$ & Methanol & $30: 1-60: 1$ & - & $320-350$ & $\begin{array}{l}45: 1,335^{\circ} \mathrm{C} \\
20 \mathrm{MPa}\end{array}$ & $89.9 / 15$ & [78] \\
\hline Lamb fat & Tubular & Methanol & $3: 1-6: 1$ & $\begin{array}{l}\text { C. antarctica (Novozyme } 435 \text { ) } \\
\text { lipase in } \mathrm{SC} \mathrm{CO}_{2} / 30-50\end{array}$ & $35-60$ & $\begin{array}{l}4: 1,50 \% \\
50{ }^{\circ} \mathrm{C} \\
20 \mathrm{MPa}\end{array}$ & $(49.2) / 1500^{a}$ & [77] \\
\hline Lamb fat & Packed bed, 10/- & Methanol & $5: 1-20: 1$ & $\begin{array}{l}\text { C. antarctica (Novozyme 435) } \\
\text { lipase in } \mathrm{SC} \mathrm{CO}_{2} / 3.27 \mathrm{~g}\end{array}$ & 50 & $10: 1,20 \mathrm{MPa}$ & $53.5 / 60^{\mathrm{a}}$ & [81] \\
\hline
\end{tabular}

${ }^{\text {a }}$ Residence time.

[80]. The residence time affects the biodiesel yield under supercritical conditions. The ester yield in a tubular reactor initially increased as the residence time increased to a maximum value and then decreased at longer residence times, which was attributed to the thermal decomposition of initially formed FAME under supercritical conditions [80].

The main disadvantage of supercritical processes, like an extremely high temperature and thus intensive energy requirement, can be overcome by the application of enzymes in the presence of supercritical carbon dioxide $\left(\mathrm{SC}-\mathrm{CO}_{2}\right)[77,81]$. When WAFs, which have a high melting point close to the denaturation temperature of lipase, are used for transesterification reaction, they must be dissolved in a solvent. Because organic solvents may have a harmful effect for human health, $\mathrm{SC}-\mathrm{CO}_{2}$ can be proposed as a good alternative for this purpose because it is non-toxic, has a low critical temperature below the denaturation temperature of lipase and easily dissolve non-polar molecules like TAGs. In addition, $\mathrm{SC}-\mathrm{CO}_{2}$ offers easy product separation and does not require solvent recovery unit. The use of $\mathrm{SC}-\mathrm{CO}_{2}$, which is a high cost process, may be justified when the feedstock is in solid form, as in the case of animal fats [77]. Some authors [81,77] applied lipases for transesterification of waste lamb fat using $\mathrm{SC}-\mathrm{CO}_{2}$ and demonstrated that this process had many advantages. Beside low temperature, there is no need for feedstock purification, and lipase is capable of transesterification of TAGs and esterification of FFAs present in the feedstock. However, the optimum ester yields obtained in the presence of lipase Novozym 435 are low (about 50\%) in the both cases.

Taher et al. [77] investigated the effects of enzyme loading, reaction temperature and methanol:fat molar ratio on ester yield and concluded that ester yield increased with both enzyme loading and time. Up to $5 \mathrm{~h}$, the FAME yield increased linearly with increasing the amount of enzyme, and then the effect started to deviate. This was due to approaching the equilibrium yield as time increased, and hence the effect of lipase loading tended to diminish. Actually, the ester yield increased significantly as the lipase loading increased from $10 \%$ to $30 \%$, but the higher enzyme amount was not recommended because of high cost of enzyme.

The increase of reaction temperature resulted in an increase of FAME yield due to the increase in rate constants and the reduction in mass transfer limitations. However, the increase in temperature resulted in a decrease in ester yield because of denaturation of the lipase. The critical temperature at which the lipase started to deactivate was different and depended on the lipase type and immobilized surface.

The increase of methanol:fat molar ratio above the stoichiometric one up to an optimum value resulted in the increased ester yield, but after that the ester yield decreased because of lipase inhibition by methanol [77].

Al-Zuhair et al. [81] combined a continuous process of fat extraction from meat and ester synthesis with the use of SC- $\mathrm{CO}_{2}$ in an integrated system which seemed to be economically feasible. The decrease in enzyme activity was observed in the third meat replacement cycle of the continuous experiment, compared to that of the first one. The inhibition effect of methanol was clearly observed from the higher drop in enzyme activity with the increase of methanol:fat molar ratio. The results showed that the production yield dropped rapidly as the methanol:fat molar ratio increased. In the first meat cycle with fresh enzyme and higher methanol:fat molar ratio, the highest ester yield was achieved. This could be explained by the increase in substrate concentration, which had a positive effect on the reaction rate.

\section{Optimization and kinetics of WAF transesterification}

\subsection{The statistical optimization of WAF transesterification}

There are a number of useful statistical techniques, i.e. designs of experiments, which have been applied for optimization of biodiesel production parameters. In this way, it will help to understand the process much better and to provide more efficient and more economic processes.

The homogeneously catalyzed alcoholysis of WAFs have been frequently optimized by using the response surface methodology (RSM) combined with the central composite design (CCD) [50], central composite rotatable design (CCRM) [52], factorial design [30], the combination of full factorial and Doehlert matrix design [82], as well as the combination of full factorial and general linear model [83]. Tashtoush et al. [30] performed their experiments of acid catalyzed alcoholysis of a WAF to determine the optimum operating conditions using a factorial design with three factors. The greatest influence on the ester yield had reaction temperature, alcohol:oil molar ratio, alcohol type and catalyst type. Mendonca et al. [82] applying a full factorial design reported that, in the decreasing order, the alcohol:beef tallow molar ratio, the alcohol:base catalyst mass ratio, reaction time and their reciprocal interaction were effective on the esters yield. The response variables were purity and yield of the final biodiesel product. An increase in reaction temperature had a negative influence on purity while only methanol:tallow molar ratio had a significant positive influence on ester yield. Quadratic models for purity and yield were obtained using the Doehlert matrix, and the Lagrange criterion was used for the determination of the second- 
order equation critical point. RSM and CCD with five levels were employed to estimate the influence of base catalyst amount, methanol:tallow molar ratio and radio-frequency heating time on the conversion rate [50]. The catalyst concentration was found to have the largest positive effect. Jeong et al. [52] optimized the reaction conditions (temperature, catalyst amount and methanol:fat molar ratio) of biodiesel production from lard using a base catalyst. They applied RSM combined with CCRM to delineate the effects of fivelevel-three-factors and their reciprocal interaction on biodiesel production. The statistical model predicted the highest conversion of 98.6\%. Using optimum factor values in three independent replicates, an average content of $97.8 \%$ was achieved, which was very close to the value predicted by the model. The authors concluded that the RSM can be applied effectively to the optimization of the biodiesel production from lard. Berrios et al. [83] reported that a $3^{2}$ factorial design (two factors each at three levels) can be applied to determine the influence of agitation speed and the base catalyst amount on the FAME concentration. This method was used in order to reduce the number and the cost of experiments performed for optimizing the biodiesel production from lard. The response was fitted to the factors through a general linear model. The statistical analysis of the experimental range studied showed the catalyst concentration as the most important factor affecting the response. The interaction between two factors was not very significant but had a negative influence.

The heterogeneously-catalyzed processes of biodiesel synthesis from WAFs have been rarely statistically optimized. Dias et al. [43] applied the RSM for the optimization of the reaction conditions in the case of the biodiesel synthesis from pork lard in the presence of a solid catalyst. Three factors (temperature, catalyst concentration and methanol:fat molar ratio) and two central points were considered using the RSM combined with the CCD. The RSM study allowed the development of a second-order polynomial model which considered the linear, quadratic and the interaction effects of the variables. The model determines the influence of temperature and the combined effect of temperature and catalyst concentration on the biodiesel purity.

A few studies have dealt with the optimization of enzymecatalyzed methanolysis of WAFs. Huang et al. [39] employed the RSM and multiple linear regression procedures to determine the optimum reaction conditions for biodiesel synthesis from lard catalyzed by the combined use of two immobilized lipases (Novozym 435 and Lipozyme TLIM). Under the optimum conditions, the highest predicted and actual ester yields were $97.6 \%$ and $97.2 \%$, respectively, when proportion of the two lipases was $0.49 \mathrm{w} / \mathrm{w}$. The statistical procedures of general linear model (PROC GLM) and PROC MIXED were both used by Aryee et al. [74], who developed a model describing well the effects of the reaction variables on FAEE yield. A comparison of classification and regression models at discrete time by using the PROC GLM revealed that the former was a significant improvement over the latter. Therefore, the PROC MIXED model with repeated measures was chosen and utilized for the data analysis and presentation. This study revealed that ester yield significantly differed with the progress of the reaction and was dependent on temperature, alcohol:fat molar ratio and reaction time. The optimum conditions for the microwave-assisted enzymatic synthesis of biodiesel were developed by a $2^{2}$ full factorial design leading to a set of seven runs with different combinations of ethanol:tallow molar ratio and temperature [76]. Under optimum conditions of molar ratio and temperature, almost total conversion of FFAs present in the original beef tallow occurred. This represented a six fold increase for the process carried out under conventional heating.

\subsection{Kinetics of WAF transesterification}

The knowing of transesterification reaction kinetics is very important for the operation, design and scale-up of reactors and is necessary for development of mathematical models describing the reaction rate and the biodiesel yield. There is no study on the kinetics of the homo- and heterogeneously-catalyzed alcoholysis reaction of WAFs. For the enzyme-catalyzed reaction, only Taher et al. [77] determined the initial maximum velocity of the reaction, apparent Michaelis-Menten constants for fat and methanol and apparent methanol inhibition constant. In this investigation, the experimental results of lipase-catalyzed lamb fat methanolysis by $\mathrm{SC}-\mathrm{CO}_{2}$ were used to fit a suitable reaction kinetic model using non-liner regression analysis and to determine the model parameters. In order to estimate the kinetic parameters, a graphical illustration of the initial reaction rate against the amount of methanol was used. Initial rates were determined from dependence of ester yield on reaction time for different methanol concentrations. The authors verified that the reaction kinetics studies follows ping-pong $\mathrm{Bi}-\mathrm{Bi}$ model with competitive alcohol inhibition and defined the simplified kinetic equation linking the initial reaction rate with the initial methanol mass concentration. Also, a model equation was developed.

\section{Reactors used in biodiesel production}

Different reactor design has been used in the biodiesel production from WAFs. The simplest way to realize transesterification reaction to produce biodiesel from WAFs is using laboratory batch stirred reactors (vials, flasks or autoclave) with different types of impellers. Pilot batch reactors and continuous tubular and packedbed reactors are rarely used. Ultrasonic, microwave and reactors with radio-frequency heating are shown to be very promising for biodiesel production.

In the batch homogeneously- and heterogeneously-catalyzed processes, stirred reactors are equipped with mechanical impellers $[17,21,31,32,35,47,52,71]$ or magnetic stirrers $[12,36-38,40,41,43$, $50,51,53,60,61,70]$. In some cases, shakers are applied [33,34,55]. The most commonly used method for reaction mixture stirring in the enzyme-catalyzed processes was reciprocal shaking [39,74,75].

Da Cunha et al. [32] concluded that the base transesterification of beef tallow with methanol can be successfully carried out in the pilot plant, but the economical viability must be improved by recovering of methanol and glycerol. This study was a first step for the construction of an industrial plant for biodiesel production with capacity of $120,000 \mathrm{~kg} /$ day.

Tubular reactors were used as very promising reactors in the continuous methanolysis of WAFs using base catalyst [6] and SC$\mathrm{CO}_{2}$ [80] because of very high conversion. When effects of lipases and $\mathrm{SC}-\mathrm{CO}_{2}$ on waste lamb fat transesterification reaction in the tubular [77] and continuous packed-bed [81] reactors were combined, the achieved ester yields were low (about 50\%) in both cases. An integrated process for continuous enzymatic production of biodiesel under supercritical condition from extracted lamb fat in the packed bed arrangement was selected by Al-Zuhair et al. [81], because this reactor type has lower mechanical shear forces compared to stirred reactors. Also, the activity of solid catalyst was confirmed in a continuous flow packed-bed reactor system where esterification of oleic acid as model for brown grease with methanol was performed [68].

Novel types of reactors such as ultrasonic reactors, reactors with microwave irradiation and reactors with radio frequency heating have been recently employed in biodiesel production. The use of ultrasonic reactors can overcome the problem of long reaction time required in stirred tank reactors [31]. The significant reduction of reaction time was achieved in the reaction with both homogeneous and heterogeneous catalysts [54]. For the heterogeneous catalyst $\left(\mathrm{KOH} / \gamma-\mathrm{Al}_{2} \mathrm{O}_{3}\right)$, ultrasonic mixing reduces the reaction and phase-separation time (77\% and 50\%, respectively), 
as well as the activity of the solid catalyst. The duration of biodiesel synthesis and the negative effects of some reaction conditions on the enzyme catalyst can be reduced in the reactor with microwave irradiation [76]. Reactors with radio frequency heating are simpler in comparison with microwave heating and more economical when applied in large scale [50].

\section{Limitations, improvement and economics of biodiesel production from WAFs}

\subsection{The limitations of WAFs as feedstocks for biodiesel production}

The production of biodiesel from WAFs has certain limitations and concerns that have to be overcome, such as the presence of proteins, phosphoacylglycerols, water, FFAs, SFAs, pathogens etc.

WAFs usually contain more protein and phosphoacylglycerols (so-called gums) because they are components of animal cell membranes and remain in the lipids fraction. For this reason, a degumming process is used to eliminate the phosphoacylglycerols from fats before their use in biodiesel production. The most commonly used process for fats degumming is treatment with $60 \%$ orthophosphoric acid, after which the gums can be separated by centrifugation [84].

Another disadvantage of WAFs is the presence of water which amount depends on storage conditions, storage time, animal fats container, humidity and temperature. WAFs contain significant amount of water compared to vegetable oils. Therefore, atmospheric or vacuum drying is usually applied to solve moisture content problems.

Due to high content of FFAs in WAFs, initial FFA esterification in the presence of acid catalyst is required before the base-catalyzed transesterification [85]. This two-step acid/base process is also applied in the case of biodiesel production from vegetable oils with higher acid value such as nonedible or waste oils.

The higher amount of SFAs in WAFs, compared to vegetable oils, causes the higher clouding point and CFPP of WAFs biodiesel which limit it its use inconvenient in cold climate conditions. To improve the cold-temperature properties and obtain biodiesel that meets the standard limitation, different methods are applied: elimination of SFAs (known as winterization), addition of additives or mixing with vegetable oils biodiesel [86].

The difficulty in biodiesel production from WAFs is the possible presence of pathogenic prions which could lead to contaminated biodiesel and hence to a possible risk for the environment and humans. Seidel et al. [87] found out that the esterification step catalyzed by sulfuric acid leads to an effective inactivation of pathogens, especially at high temperatures. According to their results, the biodiesel produced from material with a high concentration of pathogens can be considered as safe, which was attributed to a high oxidative potential of sulfuric acid.

\subsection{The possibilities for improvement of WAF transesterification}

The improvement of the transesterification reaction of WAFs includes all methods that increase the conversion rate, shorten the reaction time and/or simplify the process. Recently, several different novelties have been used aiming at the improvement of the biodiesel production from WAFs such as the use of ultrasonic irradiation, microwave and radio frequency heating. The use of co-solvents can enhance the conversion rate only in the presence of homogeneous catalysts but not in the presence of solid catalysts.

TAG methanolysis using ultrasonic irradiation is an effective, feasible, time saving and economical way for biodiesel production from WAFs. The ultrasonic irradiation increases the interaction between the immiscible liquids due to a collapse of the cavitation bubbles and ultrasonic jets that impinge methanol to TAGs and cause emulsification. These actions enhance the mass transfer and chemical reaction rates and thus shorten reaction time and increase ester yield.

Teixeira et al. [31] compared conventional and ultrasonic preparation of beef tallow biodiesel and concluded that reaction conversion and biodiesel quality were similar in the both methods. However, the use of ultrasonic irradiation was more effective due to reducing the reaction time from $1 \mathrm{~h}$ to $70 \mathrm{~s}$. In this case, a good conversion of TAGs (about 92\%) was realized. Also, Huong et al. [54] achieved a high ester yield (about 93\%) using fish fat as the feedstock and showed that the amplitude of ultrasonic waves and reaction time had significant effects on the transesterification reaction and the obtained yield. For short reaction times, increasing ultrasonic amplitude resulted in a continuous increase in the yield. However, with longer reaction times, the high ester yield was achieved only at the low amplitude. Also, with the same amplitude, the longer reaction time resulted in the higher ultrasonic energy. When the ultrasonic energy increased, the yield of biodiesel increased, reached the maximum and then started to decline due to degradation. Ultrasonic heating also reduced the reaction time of the solid catalyzed process [54]. Actually, ultrasound reduced the activity of the solid catalyst. After the completion of transesterification, the collected solid catalyst could be refreshed by loading an additional catalyst amount and then could be reused [54].

Da Rós et al. [76] showed that microwave assistance of biodiesel synthesis from beef tallow could speed up the enzyme catalyzed reaction, decrease the destructive effects on the enzyme for the operational conditions (higher temperature, stability, specificity to its substrate) and allow the entire reaction medium to be heated uniformly. Almost total conversion of the FFAs from raw material was achieved using ethanol and lipase from Burkholderia cepacia immobilized on silica-PVA.

Radio frequency is another dielectric heating technology with similar mechanism with microwave heating. Compared to microwave heating, it is simpler with respect to the system configuration, has higher electricity to electromagnetic power conversion efficiency and has deeper energy penetration into the material [50]. In this way, it is more economical and more suitable to be applied in large scale reactors. Under radio frequency heating, the high conversion (96.3\%) was obtained in very short reaction time $(5 \mathrm{~min})$ of the base-catalyzed transesterification of beef tallow [50]. It was showed that the conversion rate increased with the increasing radio frequency heating time.

Liu et al. [67] investigated the effect of co-solvent on conversion of TAGs from poultry fat in the presence of solid catalyst. The introduction of co-solvent ( $n$-hexane, toluene or tetrahydrofurane, THF) in the reaction mixture can impact reaction rate by modifying substrate interaction with catalyst surface and decrease fat conversion compared to the system without the cosolvent. A non-polar co-solvent, such as $n$-hexane and toluene, interacts with TAGs more easily than the polar methanol, favoring the reaction rate. On the other hand, MAGs and DAGs with polar hydroxyl groups and non-polar long alkyl chains are the strong surface agents that easily form emulsions. $n$-Hexane, for instance, has been found to improve the emulsion characteristics of MAGs and DAGs. All of these factors, combined with methanol depletion during reaction, may explain the observed reactivity differences for reaction using $n$-hexane and toluene. Further, Liu et al. [67] showed that THF as a co-solvent gave rise to a much lower catalyst activity for the methanolysis of poultry fat in the presence of solid catalyst due to facilitation of other deactivation routes involving the chemical species in the reaction. THF dissolves efficiently poultry fat and methanol, 
Table 9

The comparison manufacturing cost for biodiesel production using different oily feedstocks, and processes.

\begin{tabular}{|c|c|c|c|c|c|}
\hline Oil feedstock & Process type & Catalyst & Plant capacity, ton/year & Total manufacturing cost, US\$/ton & Reference \\
\hline \multirow[t]{3}{*}{ Soybean oil } & \multirow[t]{3}{*}{ Continuous } & \multirow[t]{3}{*}{$\mathrm{NaOH}$} & 8000 & 862 & \multirow[t]{3}{*}{ [88] } \\
\hline & & & 30,000 & 724 & \\
\hline & & & 100,000 & 678 & \\
\hline \multirow[t]{4}{*}{ WCO } & \multirow[t]{4}{*}{ Continuous } & $\mathrm{H}_{2} \mathrm{SO}_{4}$ & 8000 & 650 & \multirow[t]{4}{*}{ [89] } \\
\hline & & $\mathrm{H}_{2} \mathrm{SO}_{4} / \mathrm{NaOH}$ & & 595 & \\
\hline & & SnO & & 485 & \\
\hline & & none & & 570 & \\
\hline \multirow[t]{3}{*}{ WCO } & \multirow[t]{3}{*}{ Continuous } & \multirow[t]{3}{*}{ none } & 8000 & 150 & \multirow[t]{3}{*}{ [90] } \\
\hline & & & 80,000 & 214 & \\
\hline & & & 125,000 & 442 & \\
\hline \multirow[t]{2}{*}{ WCO } & \multirow[t]{2}{*}{ Batch } & $\mathrm{KOH}$ & 7260 & $598^{\mathrm{a}}$ and $641^{\mathrm{b}}$ & \multirow[t]{2}{*}{ [91] } \\
\hline & & $\mathrm{CaO}$ & & $584^{\mathrm{a}}$ and $622^{\mathrm{b}}$ & \\
\hline Fresh canola oil & \multirow[t]{3}{*}{ Continuous } & $\mathrm{NaOH}$ & 40,000 & 1145 & \multirow[t]{3}{*}{ [92] } \\
\hline Waste canola oil & & $\mathrm{H}_{2} \mathrm{SO}_{4} / \mathrm{NaOH}$ & & 875 & \\
\hline Waste canola oil & & None & & 725 & \\
\hline Beef tallow & Continuous & Alkali & 100,000 & 340 & [93] \\
\hline
\end{tabular}

${ }^{a}$ Water biodiesel purification process

${ }^{\mathrm{b}}$ Vacuum FAME distillation process.

resulting in a more homogeneous distribution of species between both the liquid media and the catalyst surface. The latter effect allows greater competition by TAGs for surface active sites, giving rise to a higher catalyst deactivation than that observed for the reaction without the co-solvent.

\subsection{The economics of biodiesel production}

A major obstacle in the industrial biodiesel production is its high manufacturing cost. Generally, the significant factors that affect the cost of biodiesel production are feedstock cost, applied technology and plant capacity as well as value of the glycerol byproduct. The comparison of economic assessment for biodiesel production using various feedstock and different processes is given in Table 9.

Biodiesel production cost decreases with increasing plant capacity. In supercritical continuous biodiesel production process from waste cooking biodiesel, price decreases from 0.52 US\$/L to 0.17 US\$/L when plant capacity increases from $8000 \mathrm{t} / \mathrm{year}$ to $125,000 \mathrm{t} /$ year [90]. According to West et al. [89], the biodiesel production cost for a plant capacity depends on the catalyst type, and the heterogeneously catalyzed process is the most profitable. Similar result was reported by Sakai et al. [91]. The most sensitive key factor for the economic feasibility of biodiesel production is the raw material cost. Waste cooking oils and animal fats, which are much less expensive than pure vegetable oils, are promising alternative to vegetable oil for biodiesel production. Bender [94] reviewed the economic feasibility of biodiesel production, involving different oily feedstocks and reported that the calculated production cost for fuel produced from animal fats was the lowest (in the range from $0.32-0.37 \mathrm{US} \$ / \mathrm{L}$ ). However, the biodiesel production cost has been often more lower in the case of WCOs than in the case of animal fats. Nelson et al. [93] evaluated the economic feasibility of the biodiesel production from beef tallow. The estimated total manufacturing cost in the plant of capacity of approximately $100,000 \mathrm{t} /$ year is $340 \mathrm{US} \$ / \mathrm{t}$, which is much less compared to the costs from other feedstocks. Therefore, WAFs are promising feedstocks to make biodiesel more competitive, mainly in regions with intensive livestock. However, the WAFs amount depends on the food industries, information on their productivity is deficient and their amount is usually insufficient for biodiesel production.

\section{Conclusions}

Biodiesel, an alternative fuel, chemically consisted from fatty acid alkyl esters, is derived from the vegetable oils and animal fats. However, the use of biodiesel has not expanded into developing countries, because it is not competitive in prices with petroleum diesel. The use of low-cost feedstocks such WAFs can make biodiesel cost close to conventional diesel. The most common way to produce biodiesel from WAFs is by transesterification reaction, which can be homogeneously-, heterogeneously-, enzymatically- or non-catalyzed (supercritical alcohol conditions) reaction. Although the one- and two-step (acid/base) homo- and heterogeneously catalyzed processes can be very useful for converting WAFs into biodiesel, novel technologies based on the application of enzymes, ultrasonic irradiation, microwaves and radio-frequency heating have been emerging recently.

\section{Acknowledgment}

This work has been funded by the Ministry of Education, Science and Technological Development of the Republic of Serbia (Project III 45001).

\section{References}

[1] Balat M, Balat $H$. Progress in biodiesel processing. Appl Energy 2010;87:1815-35.

[2] Balat M. Potential alternatives to edible oils for biodiesel production - a review. Energy Convers Manag 2011;52:1479-92.

[3] Fan X, Burton R. Recent development of biodiesel feedstocks and the applications of glycerol: a review. Open Fuels Energy Sci J 2009;2:100-9.

[4] Gui MM, Lee KT, Bhatia S. Feasibility of edible oil vs. non-edible oil vs. waste edible oil as biodiesel feedstock. Energy 2008;33:1646-53.

[5] Leung DYC, Wu X, Leung MKH. A review on biodiesel production using catalyzed transesterification. Appl Energy 2010;87:1083-95.

[6] Moraes MSA, Krause LC, da Cunha ME, Faccini CS, de Menezes EW, Veses RC, et al. Tallow biodiesel: Properties evaluation and consumption tests in a diesel engine. Energy Fuel 2008;22:1949-54.

[7] United States Department of Agriculture USDA, Foreign agricultural service, 〈http://www.fas.usda.gov/psdonline/〉 [accessed July 2013].

[8] Swisher KJ. The global market for rendered products, 〈http://assets.national renderers.org/essential_rendering_global_market.pdf〉 [accessed July 2013].

[9] AOCS Lipid Library 〈http://lipidlibrary.aocs.org/processing/animalfats/index. htm $>$ [accessed July 2013].

[10] Canakci M. The potential of restaurant waste lipids as biodiesel feedstocks. Bioresour Technol 2007;98:183-90. 
[11] Karmakar A, Karmakar S, Mukherjee S. Properties of various plants and animals feedstocks for biodiesel production. Bioresour Technol 2010;101: 7201-7210.

[12] Öner C, Altun S. Biodiesel production from inedible animal tallow and an experimental investigation of its use as alternative fuel in a direct injection diesel engine. Appl Energy 2009;86:2114-20.

[13] Janaun J, Ellis N. Perspectives on biodiesel as a sustainable fuel. Renew Sustain Energy Rev 2010;14:1312-20.

[14] Goering CE, Schwab AW, Dangherty MJ, Pryde EH, Heakin AJ. Fuel properties of eleven vegetable oils. Trans ASAE 1982;25(6):1472-7.

[15] Canakci M, Van Gerpen J. Biodiesel production from oils and fats with high free fatty acids. Trans ASAE 2001;44(6):1429-36.

[16] Arnaud E, Trystram R, Relkin P, Collignan A. Thermal characterization of chicken fat dry fractionation process. J Food Eng 2006;72:390-7.

[17] Chung KH, Kim J, Lee KY. Biodiesel production by transesterification of duck tallow with methanol on alkali catalysts. Biomass Bioenergy 2009:33:155-8.

[18] Panneerselvam SI, Miranda LR. Biodiesel production from mutton tallow. Int J Renew Energy Res 2011;1:45-9.

[19] Lee KT, Foglia TA, Chang KS. Production of alkyl ester as biodiesel from fractionated lard and restaurant grease. J Am Oil Chem Soc 2002;79(2):191-5.

[20] Thamsiriroj T, Murphy JD. How much of the target for biofuels can be met by biodiesel generated from residues in Ireland? Fuel 2010;89:3579-89.

[21] Ngo HL, Zafiropoulos NA, Foglia TA, Samulski ET, Lin W. Efficient two-step synthesis of biodiesel from greases. Energy Fuel 2008;22:626-34.

[22] BDI-BioEnergy International AG, 〈http://www.bdi-bioenergy.com $\rangle$ [accessed July 2013].

[23] Independent Statistics and Analysis, US energy information administration, monthly biodiesel production report, 〈http://www.eia.gov/biofuels/biodiesel/ production/?src=renewable-b1 $>$ [accessed July 2013].

[24] Biofuel production from animal fats-the World renderers $\langle$ http://www.worl drenderers.org $>$ [accessed July 2013].

[25] Independent Statistics and Analysis, US energy information administrator international energy statistics, 〈www.eia.gov.oiaf/analysispaper/biodiesel) [accessed July 2013]

[26] Zhang Y, Dube MM, McLean DD, Kates M. Biodiesel production from waste cooking oil: 1. Process design and technological assessment. Bioresour Techno 2003;89(1):1-16.

[27] Rice B, Fröhlich A, Leonard R. Biodiesel production from camelina oil, waste cooking oil and tallow. Dublin: Teagasc; 1998.

[28] Enweremadu CC, Mbarawa MM. Technical aspects of production and analysis of biodiesel from used cooking oil - a review. Renew Sust Energy Rev 2009;13:2205-24.

[29] Veljković VB, Banković-Ilić IB, Stamenković OS, Hung Y-T. Waste vegetable oils, fats and cooking oils in biodiesel production. In: Hung Y-T, Wang LK, Shammas NK, editors. Advanced waste treatment in food processing industry. Boca Raton, Fl, USA: CRC Press, Taylor \& Francis Group; 2014 (in press).

[30] Tashtoush GM, Mohamad I, Al-Widyan M, Al-Jarrah M. Experimental study on evaluation and optimization of conversion of waste animal fat into biodiesel. Energy Convers Manag 2004;45:2697-711.

[31] Teixeira LSG, Assis JCR, Mendonça DR, Santos ITV, Guimarães PRB, Pontes LAM. Teixeira JSR. Comparison between conventional and ultrasonic preparation of beef tallow biodiesel. Fuel Process Technol 2009;90:1164-6.

[32] Da Cunha ME, Krause LC, Moraes MSA, Faccini CS, Jacques RA, Almeida SR, et al. Beef tallow biodiesel produced in a pilot scale. Fuel Process Technol 2009;90:570-5.

[33] Mata TM, Cardoso N, Ornelas M, Neves S, Caetano NS. Sustainable production of biodiesel from tallow, lard and poultry fat and its quality evaluation. Energy Fuel 2010;25:4756-62.

[34] Mata TM, Cardoso N, Ornelas M, Neves S, Caetano NS. Evaluation of two purification methods of biodiesel from beef tallow, pork lard and chicken fat. Chem Eng Trans 2011;9:13-8.

[35] Panneerselvam S.I., Parthiban R., Miranda L.R., Poultry fat - a cheap and viable source for biodiesel production. In: Proceedings of the 2nd International Conference on Environmental Science and Technology IPCBEE. Singapore: IACSIT Press; 2011, 6, V1. p. 371-74.

[36] Bhatti HN, Hanif MA, Qasim M, Rehman A. Biodiesel production from waste tallow. Fuel 2008;87:2961-6.

[37] Dias JM, Alvim-Ferraz MCM, Almeida MF. Production of biodiesel from acid waste lard. Bioresour Technol 2009;100:6355-61.

[38] Dias JM, Alvim-Ferraz MCM, Almeida MF, Díaz JDM, Polo MS, Utrilla JR. Biodiesel production using calcium manganese oxide as catalyst and different raw materials. Energy Convers Manag 2013;65:647-53.

[39] Huang Y, Zheng H, Yan Y. Optimization of lipase-catalyzed transesterification of lard for biodiesel production using response surface methodology. App Biochem Biotechnol 2010;160:504-15.

[40] Alptekin E, Canakci M. Optimization of pretreatment reaction for methyl ester production from chicken fat. Fuel 2010;89:4035-9.

[41] Alptekin E, Canakci M. Optimization of transesterification for methyl ester production from chicken fat. Fuel 2011;90:2630-8.

[42] Jagadale SS, Jugulkar LM. Production and analysis of chemical properties of chicken fat based biodiesel and its various blends. Int J Eng Res Dev 2012; (7):34-7.

[43] Dias JM, Alvim-Ferraz MCM, Almeida MF, Díaz JDM, Polo MS, Utrilla JR Selection of heterogeneous catalysts for biodiesel production from animal fat. Fuel 2012;94:418-25.
[44] Salvi BL, Panwar NL. Biodiesel resources and production technologies - a review. Renew Sust Energy Rev 2012;16:3680-9.

[45] Lotero E, Liu Y, Lopez DE, Suwannakarn K, Bruce DA, Goodwin JG. Synthesis of biodiesel via acid catalysis. Ind Eng Chem Res 2005;44:5353-63.

[46] Vyas AP, Verma JL, Subrahmanyam N. A review on FAME production processes. Fuel 2010;89:1-9;

West AH, Posarac D, Ellis N. Assessment of four biodiesel production processes using HYSYS.Plant. Bioresour Technol 2008;99:6587-601.

[47] Encinar JM, Sánchez N, Martínez G, García L. Study of biodiesel production from animal fats with high free fatty acid content. Bioresour Technol 2011;102:10907-14.

[48] Kusdiana D, Saka S. Effects of water on biodiesel fuel production by supercritical methanol treatment. Bioresour Technol 2004;91:289-95.

[49] Hoque ME, Singh A, Chuan YL. Biodiesel from low cost feedstocks: the effects of process parameters on the biodiesel yield. Biomass Bioenergy 2011;35:1582-7.

[50] Liu S, Wang Y, Oh JH, Herring JL. Fast biodiesel production from beef tallow with radio frequency heating. Renew Energy 2011;36:1003-7.

[51] Fröhlich A, Rice B, Vicente G. The conversion of low grade tallow into biodiesel-grade methyl ester. J Am Oil Chem Soc 2010;87:825-33.

[52] Jeong GT, Yang HS, Park DH. Optimization of transesterification of animal fat ester using response surface methodology. Bioresour Technol 2009;100: 25-30.

[53] Dias JM, Alvim-Ferraz MCM, Almeida MF. Mixtures of vegetable oils and animal fat for biodiesel production: influence on product composition and quality. Energy Fuel 2008;22:3889-93.

[54] Huong LTT, Tan PM, Hoa TTV. Biodiesel production from fat of tra catfish via heterogeneous basic-catalyzed transesterification using ultrasonic mixing. E-J Surf Sci Nanotech 2011;9:477-81.

[55] Montefrio MJ, Xinwen T, Obbard JP. Recovery and pre-treatment of fats, oil and grease from grease interceptors for biodiesel production. Appl Energy 2010;87:3155-61.

[56] Ma F, Clements LD, Hanna MA. The effects of catalyst, free fatty acids and water on transesterification of beef tallow. Trans Am Soc Agric Eng 1998;41:1261-4.

[57] Araújo BQ da Rocha Nunes RC, de Moura CVR, de Moura EM, das Gracas Lopes Cito AM, dos SantosJr. Synthesis and characterization of beef tallow biodiesel. Energy Fuel 2010;24:4476-80.

[58] Liu K. Preparation of fatty acid methyl esters for gas-chromatographic analysis of lipids in biological materials. J Am Oil Chem Soc 1994;71(11):1179-87.

[59] Mittelbach M, Pokits B, Silberholz A. Production and fuel properties of fatty acid methyl esters from used frying oil. In: Liquid fuels from renewable resources. Proceedings of an alternative energy conference. Nashville, TN, USA: ASAE Publication; 1992. p. 74-78.

[60] Gürü M, Artukoğlu BD, Keskin A, Koca A. Biodiesel production from waste animal fat and improvement of its characteristics by synthesized nickel and magnesium additive. Energy Convers Manag 2009;50:498-502.

[61] Alptekin E, Canakci M, Sanli H. Evaluation of leather industry wastes as a feedstock for biodiesel production. Fuel 2012;95:214-20.

[62] Math MC, Kumar SP, Chetty SV. Optimization of biodiesel production from oils and fats with high free fatty acids. Indian J Sci Technol 2010;3(3):318-21.

[63] Ngo HL, Zafiropoulos NA, Foglia TA, Samulski ET, Lin W. Mesoporous silicasupported diarylammonium catalysts for esterification of free fatty acids in greases. J Am Oil Chem Soc 2010;87:445-52.

[64] Sharma YC, Singh B, Korstad J. Latest developments on application of heterogeneous basic catalysts for an efficient and ecofriendly synthesis of biodiesel: a review. Fuel 2011;90:1309-24.

[65] Mutreja V, Singh S, Ali A. Biodiesel from mutton fat using $\mathrm{KOH}$ impregnated MgO as heterogeneous catalysts. Renew Energy 2011;36:2253-8.

[66] Reddy CRV, Oshel R, Verkade JV. Room-temperature conversion of soybean oil and poultry fat to biodiesel catalyzed by nanocrystalline calcium oxides. Energy Fuel 2006;20:1310-4.

[67] Liu Y, Lotero E, Goodwin Jr JG, Mo X. Transesterification of poultry fat with methanol using $\mathrm{Mg}-\mathrm{Al}$ hydrotalcite derived catalysts. Appl Catal A-Gen 2007;331:138-48.

[68] Kim M, DiMaggio C, Yan S, Wang H, Salley SO, Ng KYS. Performance of heterogeneous $\mathrm{ZrO} 2$ supported metaloxide catalysts for brown grease esterification and sulfur removal. Bioresour Technol 2011;102:2380-6.

[69] Bianchi CL, Boffito DC, Pirola C, Ragaini V. Low temperature de-acidification process of animal fat as a pre-step to biodiesel production. Catal Let 2010;134:179-83.

[70] Soldi RA, Oliveira ARS, Ramos LP, César-Oliveira MAF. Soybean oil and beef tallow alcoholysis by acid heterogeneous catalysis. Appl Catal A-Gen 2009;361:42-8.

[71] Melero JA, Bautista LF, Iglesias J, Morales G, Sánchez-Vázquez R. Zr-SBA-15 acid catalyst: optimization of the synthesis and reaction conditions for biodiesel production from low-grade oils and fats. Catal Today 2012;195 (1):44-53.

[72] Semwal S, Arora AK, Badoni RP, Tuli DK. Biodiesel production using heterogeneous catalysts. Bioresour Technol 2011;102:2151-61.

[73] Da Rós PCM, Silva GAM, Mendes AA, Santos JC, de Castro HF. Evaluation of the catalytic properties of Burkholderia cepacia lipase immobilized on noncommercial matrices to be used in biodiesel synthesis from different feedstocks. Bioresour Technol 2010;101:5508-16. 
[74] Aryee ANA, Simpson BK, Cue RI, Phillip LE. Enzymatic transesterification of fats and oils from animal discards to fatty acid ethyl esters for potential fuel use. Biomass Bioenergy 2011;35:4149-57.

[75] Lu J, Nie K, Xie F, Wang F, Tan T. Enzymatic synthesis of fatty acid methyl esters from lard with immobilized Candida sp. 99-125. Process Biochem 2007;42:1367-70.

[76] Da Rós PCM, de Castro HF, A.K.F. Carvalho, C.M.F. Soares, de Moraes FF, Zanin GM. Microwave-assisted enzymatic synthesis of beef tallow biodiesel. J Ind Microbiol Biotechnol 2012;39:529-36.

[77] Taher $\mathrm{H}, \mathrm{Al}-\mathrm{Zuhair} \mathrm{S}$, Al-Marzouqui A, Hashim I. Extracted fat from lamb meat by supercritical $\mathrm{CO}_{2}$ as feedstock for biodiesel production. Biochem Eng J 2011;55:23-31.

[78] Shin HY, Lee SH, Ryu JH, Bae SY. Biodiesel production from waste lard using supercritical methanol. J Supercrit Fluid 2012;61:134-8.

[79] Marulanda VF, Anitescu G, Tavlarides LL. Investigations on supercritical transesterification of chicken fat for biodiesel production from low-cost lipid feedstocks. J Supercrit Fluid 2010;54:53-60.

[80] Marulanda VF, Anitescu G, Tavlarides LL. Biodiesel fuels through a continuous flow process of chicken fat supercritical transesterification. Energy Fuel 2010;24:253-60.

[81] Al-Zuhair S, Hussein A, Al-Marzouqi AH, Hashim I. Continuous production of biodiesel from fat extracted from lamb meat in supercritical $\mathrm{CO}_{2}$ media. Biochem Eng J 2012;60:106-10.

[82] Mendonça DR, Andrade HMC, Guimarães PRB, Vianna RF, Meneghetti SMP, Pontesf LAM, et al. Application of full factorial design and Doehlert matrix for the optimisation of beef tallow methanolysis via homogeneous catalysis. Fuel Process Technol 2011;92:342-8.

[83] Berrios M, Gutiérrez MC, Martín MA, Martín A. Application of the factoria design of experiments to biodiesel production from lard. Fuel Process Technol 2009;90:1447-51.
[84] Canoira L, Rodríguez-Gamero M, Querol E, Alcántara R, Lapuerta M, Oliva F. Biodiesel from low-grade animal fat: production process assessment and biodiesel properties characterization. Ind Eng Chem Res 2008;47:7997-8004.

[85] Sawangkeaw R, Ngamprasertsith S. A review of lipid-based biomasses as feedstocks for biofuels production. Renew Sust Energy Rev 2013;25:97-108.

[86] Lebedevas S, Vaicekauskas A, Lebedeva G. Use of waste fats of animal and vegetable origin for the production of biodiesel fuel: quality, motor properties, and emissions of harmful components. Energy Fuel 2006;20:2274-80.

[87] Seidel B, Alm M, Peters R, Kördel W, Schäffer A. Safety evaluation for a biodiesel process using prion-contaminated animal fat as a source. Environ Sci Pollut Res 2006;13:125-30.

[88] You Y, Shie J, Chang C, Huang S, Pai C, Yu Y, et al. Economic cost analysis of biodiesel production: case in soybean oil. Energy Fuels 2008;22:182-9.

[89] West AH, Posarac D, Ellis N. Assessment of four biodiesel production processes using HYSYS plant. Bioresour Technol 2008;99:6587-601.

[90] Van Kasteren JMN, Nisworo AP. A process model to estimate the cost of industrial scale biodiesel production from waste cooking oil by supercritical transesterification. Resour Conserv Recycl 2007;50:442-58.

[91] Sakai T, Kawashima A, Koshikawa T. Economic assessment of batch biodiesel production processes using homogeneous and heterogeneous alkali catalysts. Bioresour Technol 2009;100:3268-76.

[92] Lee S, Posarac D, Ellis N. Process simulation and economic analysis of biodiesel production processes using fresh and waste vegetable oil and supercritical methanol. Chem Eng Res Des 2011;89:2626-42.

[93] Nelson RG, Hower SA, Weber JA. Potential feedstock supply and costs for biodiesel production. Bioenergy 1994. In: Proceedings of the Sixth National Bioenergy Conference. Reno/Sparks, NV; 1994.

[94] Bender M. Economic feasibility review for community-scale farmer cooperatives for biodiesel. Bioresource Technol 1999;70:81-7. 